\section{HUELLAS DEL PROCESO DE METROPOLIZACIÓN EN CHILE'}

Arturo Maximiliano Orellana Ossandón², Pedro Bannen Lanata ${ }^{3}$, Luis Alejandro Fuentes Arce ${ }^{4}$, Horacio Gilabert Peralta ${ }^{5}$ y Karen Pape Casale ${ }^{6}$

\section{Resumen}

Este trabajo analiza los cambios en la calidad de vida urbana en las principales áreas metropolitanas del país en la última década: Gran Santiago, Gran Valparaíso y Gran Concepción. Para tal efecto, aplica el Índice de Calidad de Vida Urbana (ICVU) para determinar posibles patrones y tendencias que puedan dar señales sobre las huellas de esta metropolización. Conforme el hecho que es posible que en la próxima década dos de cada tres personas vivan en áreas metropolitanas en Chile, esta investigación pretende entregar ciertas orientaciones sobre su configuración socioterritorial a actores públicos y privados que tienen incidencia

\section{TRACES OF THE METROPOLIZATION PROCESS IN CHILE ${ }^{1}$}

Arturo Maximiliano Orellana Ossandón², Pedro BannenLanata ${ }^{3}$, Luis Alejandro Fuentes Arce ${ }^{4}$, Horacio Gilabert Peralta ${ }^{5}$, Karen Pape Casale ${ }^{6}$

\section{Abstract}

This paper analyzes the changes in the urban quality of life within the main metropolitan areas of the country over the last decade: Greater Santiago, Greater Valparaiso and Greater Concepción. To this end, the Urban Quality of Life Index (UQLI) is applied to establish the possible patterns and trends that may shed light on the traces left by this metropolization process. Taking into account that two out of three people could live in the metropolitan areas of Chile during the next decade, and as a means to contribute to the construction of more cohesive, sustainable and competitive cities, this research aims to provide 
en el desarrollo urbano, con el propósito de aportar a la construcción de urbes más cohesionadas, sustentables y competitivas.

PALABRAS CLAVE: ÁREAS METROPOLITANAS, CALIDAD DE VIDA URBANA, DESARROLLO URBANO.

Fecha de recepción: 18.06.12

Fecha de aceptación: 31.01.13

1 Difunde resultados del Proyecto CONICYT Anillos Ciencias So ciales SOC1106, de 2012, y del estudio "Índice de Calidad de Vida Urbana (ICVU)" 2002-2012, elaborado por el Núcleo de Estudios Metropolitanos del Instituto de Estudios Urbanos y Territoriales y de la Pontificia Universidad Católica de Chile, en conjunto con la Cámara Chilena de la Construcción (CChC).

2 Chile. Doctor en Geografía Humana, Magíster en Desarrollo Urbano y Economista. Jefe de Programas de Magíster, Instituto de Estudios Urbanos y Territoriales, Pontificia Universidad Católica de Chile.Email: amorella@uc.cl

3 Chile. Arquitecto, Magíster en Desarrollo Urbano. Director del Instituto de Estudios Urbanos y Territoriales, Pontificia Universidad Católica de Chile. Email: pbannen@uc.cl

4 Chile. Geógrafo, Magíster en Desarrollo Urbano, Doctor en Arquitectura y Estudios Urbanos. Docente del Instituto de Estudios Urbanos y Territoriales, Pontificia Universidad Católica de Chile. Email: Ifuentes@uc.cl

5 Chile. Ingeniero Forestal, MSc Natural Resources Management, Ph.D Forest Resources. Profesor de la Facultad de Agronomía e Ingeniería Forestal, Pontificia Universidad Católica de Chile. Email: hgilab@uc.cl

6 Chile. Arquitecto, Magíster en Desarrollo Urbano. Asistente de investigación del Instituto de Estudios Urbanos y Territoriales, Pontificia Universidad Católica de Chile. Email: kipape@uc.cl

18 revista invi № 77 / Mavo 2013 / Volumen № 28: 17-66 with guidelines on socio-territorial configuration to influential public and private sectors participating in the urban development.

\section{KEYWORDS: METROPOLITAN AREAS, URBAN QUALITY OF LIFE AND URBAN DEVELOPMENT}

Received: 18.06.12

Accepted: 31.01.13

1 The paper disseminates the results of the research project Social Sciences Rings SOC1106 CONICYT, 2012, and the study "Urban Quality of Life Index (UQLI)" 2002-2012, developed by the Metropolitan Studies Group at the Institute of Urban and Territorial Studies at the Pontifical Catholic University of Chile in conjunction with the Chilean Chamber of Construction (CChC)

2 Chile. Ph.D. in Human Geography, MA in Urban Development, Economist. Head of the Master's Program, Institute of Urban and Territorial Studies, Pontifical Catholic University of Chile. Email: amorella@uc.cl

3 Chile. Architect, MA in Urban Development. Director of the Institute of Urban and Territorial Studies, Pontifical Catholic University of Chile.Email: pbannen@uc.cl

4 Chile. Geographer, MA in Urban Development, Ph.D. in Architecture and Urban Studies. Professor, Institute of Urban and Territorial Studies, Pontifical Catholic University of Chile. Email: Ifuentes@uc.cl

5 Chile. Forest Engineer, MSc in Natural Resources Management, Ph.D. in Forest Resources. Professor, Faculty of Agronomy and Forest Engineering, Pontifical Catholic University of Chile. Email: hgilab@uc.cl

6 Chile. Architect, MA in Urban Development. Assistant researcher, Institute of Urban and Territorial Studies, Pontifical Catholic University of Chile. Email: kipape@uc.cl 


\section{Introducción}

Una de las principales tendencias del desarrollo demográfico de Chile es su fuerte concentración geográfica en áreas urbanas. El Censo de 2002 demostró que más del 86\% de los chilenos habitaban en áreas urbanas y en los resultados preliminares que arroja el Censo 2012 esta cifra ya superaría el 90\%. Adicionalmente, la población actual en Chile se aproxima a los 16,5 millones de habitantes, de los cuales prácticamente un 45\% habita en tres áreas metropolitanas principales ${ }^{7}$ : Gran Santiago con 5,8 millones de habitantes, Gran Valparaíso con 0,91 millones de habitantes y Gran Concepción con 0,96 millones de habitantes.

En este contexto de altos niveles de urbanización en el país, surge el desafío de la calidad de vida como condición intrínseca a un desarrollo urbano que promueva urbes más competitivas, cohesionadas socialmente y ambientalmente sustentables. En la agenda política y social del país se observan cada vez más frecuentemente situaciones donde se ve confrontada la ciudadanía y sus organizaciones con el Estado o con el sector privado, a veces con

7 Gran Santiago incluye las 32 comunas de la Provincia de Santiago más las comunas de Puente Alto y San Bernardo. En el caso del Gran Valparaíso son cinco comunas: Valparaíso, Viña del Mar, Concón, Quilpué y Villa Alemana. Finalmente, el Gran Concepción está compuesto por nueve comunas: Concepción, Talcahuano, Hualpén, Chiguayante, San Pedro de la Paz, Tomé, Penco, Lota y Coronel.

\section{Introduction}

Strong geographic concentration in urban areas is one of the main trends of the demographic development in Chile. The 2002 Census showed that more than $86 \%$ of Chilean population lived in urban areas and according to the preliminary findings of the 2012 Census this figure could rise to $90 \%$. In addition, current Chilean population is rising to 16.5 million, out of which $45 \%$ live in three main metropolitan areas ${ }^{7}$; Greater Santiago, with 5.8 million; Greater Valparaíso, with 0.91 million; and Greater Concepción, with 0.96 million.

In the context of high levels of urbanization, quality of life emerges as the challenge of being an intrinsic condition to an urban development that promotes more competitive, socially cohesive and environmentally sustainable cities. We can observe an increasing number of situations within the local political and social agenda in which citizens and their organizations clash with the State or the private sector -or both- in a great

7 Greater Santiago includes the 32 municipalities belonging to the Province of Santiago and the municipalities of Puente Alto and San Bernardo. Greater Valparaíso has five municipalities: Valparaíso, Viña del Mar, Concón, Quilpué and Villa Alemana. Finally, Greater Concepción is composed of nine municipalities: Concepción, Talcahuano, Hualpén, Chiguayante, San Pedro de la Paz, Tomé, Penco, Lota and Coronel. 
ambos, en un sinnúmero de proyectos, donde justamente lo que está amenazado es la calidad de vida de las personas que habitan las áreas metropolitanas principales.

Como señala Mattos 8 , "si se acepta que la actual metamorfosis urbana está condicionada estructuralmente por tendencias constitutivas de la nueva dinámica de acumulación y crecimiento, es lógico prever que toda propuesta de transformación urbana que busque impulsar modificaciones radicales en la configuración actual de estas ciudades, deberá contemplar necesariamente una previa alteración de dichas tendencias, desde que son ellas las que en última instancia han modelado la transición hacia esta nueva forma urbana". Esta nueva configuración urbana está modelando ciudades metropolitanas en Chile con importantes grados de inequidad en términos de calidad de vida entre las comunas que las conforman, particularmente en las áreas metropolitanas como se demostrará en este trabajo. De alguna manera se cumple la tesis que plantea Veltz ${ }^{9}$, que las áreas metropolitanas a escala global tienden a parecerse e internamente tienden a diferenciarse.

Nuestras ciudades metropolitanas, como es el caso de toda América Latina, no cuentan con una institucionalidad ad-hoc que gobierne, planifique y gestione desde una institucionalidad propia a su

8 Mattos, 2010.

9 Veltz, 1999.

20 revista invi № 77 / Mayo 2013 / Volumen N² 28: 17-66 number of projects that threaten the quality of life of people living in the main metropolitan areas.

According to Mattos "if we accept that the current urban metamorphosis is structurally determined by trends constituting the new dynamics of accumulation and growth, it is reasonable to anticipate that any urban transformation proposal seeking to promote radical changes within the current configuration of these cities, should necessarily consider a previous modification of such trends, since they have ultimately modeled the transition towards this new urban form. It will be shown in this paper that this new urban configuration is modeling Chilean metropolitan cities with significant degrees of inequity in terms of quality of life among the different municipalities that comprise them, especially in the metropolitan areas. Somehow, the thesis proposed by Veltz ${ }^{9}$ in which metropolitan areas tend to be alike at global scale and differ when compared internally, holds true.

Our metropolitan cities, as those of the rest of Latin America, do not have an institutional structure in charge of governing, planning and administering

8 Mattos, 2010.

9 Veltz, 1999 
escala, ya sea esta designada o elegida como es el caso de otros países ${ }^{10}$. Lo que sucede es que la acción de gobierno, planificación y gestión urbana que se expresa en el conjunto de diversas acciones de política pública, se realiza a partir de tres niveles político-administrativos de gobierno: nacional, regional y municipal ${ }^{11}$. Esta estructura de gobierno centralista y unitario del Estado chileno responde a lo establecido en el Capítulo XIII, en su articulado del 99 al 115 de la Constitución Política de la República de Chile de 1980, incluyendo sus respectivas reformas posteriores. Lo anterior también significa que solo existen dos niveles de gobierno que se eligen en forma directa por la ciudadanía, nacional y municipal, mientras que el gobierno regional en cuyos territorios se hace presente el proceso de metropolización, se constituye con la figura de un Intendente designado por el Presidente de la República y un Consejo Regional cuyos consejeros los eligen aquellos concejales que a su vez son elegidos en las elecciones municipales cada cuatro años.

10 Básicamente se hace referencia a la existencia de un Alcalde Mayor como en las principales ciudades de Colombia, donde hay una autoridad a escala metropolitana o supra municipal como en el caso de Barcelona, 0 algunas urbes brasileiras con ciertas atribuciones de carácter metropolitano.

11 Si bien se reconoce un nivel de gobierno provincial establecido en la administración del Estado chileno, sus facultades y atribuciones no tienen significancia en materia de desarrollo urbano y territorial, por eso no se considera en el análisis para estos efectos. from an institutionalism, either appointed or elected, as in the case of other countries ${ }^{10}$. This means that the urban governance, planning and administration expressed in the different public policy actions is carried out at three politicaladministrative levels of government: national, regional and municipal ${ }^{11}$. Such a centralist and unitary government structure responds to what was established by the 1980 Constitution of the Republic of Chile, Chapter XIII, articles 99 to 115, including the corresponding further amendments. As a result, there are only two levels of government elected by citizens, national and municipal. In contrast the regional government, whose territories are the scenario for the metropolization process, is represented by both a governor appointed by the President of the Republic and a Regional Council, composed of members appointed by councilors, who, in turn, are elected every four years in municipal elections.

10 It basically refers to the post of Mayor, as in the case of main Colombian cities, which have an authority at metropolitan scale; Barcelona, with authorities at supra-municipal level; or some Brazilian cities with certain municipal responsibilities.

11 While there is a provincial government recognized within the State administration, its faculties and responsibilities have no effect in terms of urban and territorial development; this is why such a government level is not considered in this analysis. 
En virtud de los antecedentes planteados, donde se reconoce que las áreas metropolitanas no cuentan con un gobierno de facto, pero al mismo tiempo es una tendencia que se impone como un desafío en los próximos años en el marco del desarrollo urbano, aproximarse a conocer cómo ha evolucionado la calidad de vida al interior de estas en la última década, resulta ser de suma importancia para orientar la acción pública y privada a futuro, propósito en el cual se inscribe este trabajo.

\section{La calidad de vida urbana}

Algunas investigaciones realizadas por organismos internacionales, como la Comisión Económica para América Latina y el Caribe (CEPAL) y el Banco Mundial, han asociado la calidad de vida al sentimiento de felicidad, satisfacción o bienestar. Sin embargo, el concentrarse solo en la subjetividad hace complejo el concepto de calidad de vida, debido a las diferencias de percepciones entre los distintos individuos. Al respecto, Fadda y Jirón ${ }^{12}$ señalan que la calidad de vida representa algo más que el nivel de vida privado o bienestar de cada persona y más bien se refiere a todos los elementos de las condiciones en las que viven las personas, es decir, fundamentalmente sus necesidades y satisfacciones. Ahora, estas contemplan múltiples dimensiones de la calidad de vida, lo cual obliga a

12 Fadda y Jirón, 1999.
Thus, acknowledging that metropolitan areas do not have a de facto government, which is a trend that emerges as a challenge for urban development in coming years, the analysis of the evolution of quality of life within these areas over the last decade is essential to guide further public and private actions; such a purpose is the aim of this research.

\section{Urban Quality of Life}

Some research carried out by international entities such as the Economic Commission for Latin America and the Caribbean (ECLAC) and the World Bank have related quality of life to the sense of happiness, satisfaction or welfare. However, given that these studies are focused only on subjectivity, the concept of quality of life turns into a complex subject due to the differences in perceptions among different individuals. In this regard, Fadda and Jirón ${ }^{12}$ point out that quality of life represents more than the level of private life or welfare of each individual, it refers to every single element of the conditions people live in, that is to say, their needs and satisfactions. These include multiple dimensions of quality of life, which makes it necessary to determine how we measure

12 Fadda and Jirón, 1999 
determinar cómo medimos el hecho que la dotación suficiente o insuficiente en términos relativos de un bien o servicio (público o privado) afecta la calidad de vida de las personas en el espacio urbano.

Para reforzar la necesidad anterior de medir la calidad de vida a través de algunas variables objetivas, basta consignar que la Organización de las Naciones Unidas para la Educación (UNESCO) a partir de un informe ${ }^{13}$ de expertos contemplaba que la recolección de datos de calidad de vida sobre la base del conteo, medición y/o ilustración de cosas físicas de parte del investigador, constituye una forma objetiva de medir y evaluar la calidad de vida. Lo anterior no invalida en ningún caso la contribución que los estudios de percepción ofrecen para conocer en qué país, ciudad o comunidad la calidad de vida constituye una demanda de mayor urgencia para las políticas de estado.

Sin perjuicio de lo anterior, dentro de los estudios más recientes sobre calidad de vida está el realizado por el Banco Interamericano de Desarrollo $(\mathrm{BID})^{14}$, en base a encuestas de percepción aplicadas en 24 países de Latinoamérica. Este estudio reconocía como limitantes de este tipo de metodologías para medir la calidad de vida el que muchas veces no reflejan directamente la realidad, ya que están influenciadas por patrones culturales, y afectadas por expectativas y aspiraciones, lo que las

13 UNESCO, 1978.

14 BID, 2008 the extent to which the sufficient or insufficient amount of a (public or private) good or service affects the quality of life of people within the urban space.

To reinforce the aforementioned need to measure quality of life by using objective variables, it is enough to point out that UNESCO, by means of a report made by experts ${ }^{13}$, considered that the collection of quality of life data based on the counting, measurement and illustration of physical elements on the part of the researcher constitutes an objective form to measure and evaluate quality of life. Yet, the latter does not invalidate the contribution of studies on perception to know the country, city or community in which quality of life is an urgent demand for State policies.

Furthermore, a research carried out by the Inter-American Bank for Development (IABD) ${ }^{14}$, based on perception surveys conducted in 24 Latin American countries, is one of the most recent studies on quality of life. This research identified the diffuse depiction of reality as one of the constraints of these methodologies aimed at measuring quality of life, since they are influenced by cultural patterns and affected by expectations and aspirations that make them variable and

13 UNESCO, 1978.

14 BID, 2008. 
hace cambiantes y a veces indescifrables. Por otro lado, estas definiciones también se concentran en asignar un papel exclusivo al sector público como garante de la satisfacción de estas necesidades. Sin embargo, hoy en día el modelo de desarrollo predominante en el mundo hace que muchas de estas necesidades sean satisfechas por el sector privado, e incluso también por la propia comunidad a través de sus actuaciones en la construcción y producción del espacio urbano.

En virtud de esta revisión bibliográfica y de los diversos problemas que hay para definir la calidad de vida urbana de manera operativa, se planteó para este estudio, considerar a la calidad de vida urbana como "las condiciones de vida objetivas de la población generadas a partir de las actuaciones y dinámicas de transformación del espacio urbano, inducidas por actores públicos, privados y la sociedad civil". De manera explícita, en esta definición se reconoce que la calidad de vida no está circunscrita exclusivamente a las actuaciones del sector público, sino que es más bien el resultado de las actuaciones de distintos actores, incluyendo al sector privado y la sociedad civil.

Por otra parte, se pretende recoger en esta definición de calidad de vida urbana su carácter complejo, reconociendo que el uso de información estadística como condición preferente permite representar de mejor manera las necesidades de toda la población en su conjunto y no solo de un segmento, así como sometimes undecipherable. In addition, these definitions are focused on assigning an exclusive role to the public sector as the guarantor of the satisfaction of these needs. However, within the current predominant development model in the world, many of these needs are satisfied by the private sector and even by the community itself through its participation in the construction and production of urban space.

In the light of this bibliographic review and the different problems to define urban quality of life from an operative perspective, this research sees urban quality of life as "the objective life conditions of the population generated by actions and dynamics of transformation of the urban space produced by public and private actors and civil society." This statement explicitly recognizes that quality of life is not restricted to the actions of the public sector, but is the result of the intervention of different actors, including the private sector and civil society.

In addition, this research seeks to embrace the complex nature of this urban quality of life concept by acknowledging that the use of statistical information as preferential condition allows both a better representation of the needs of a population as a whole and the identification of favorable or unfavorable conditions. Likewise, in 
identificar el ámbito donde existen condiciones favorables o desfavorables. Por otro lado, si se desea hacer una análisis intertemporal de la calidad de vida en las áreas metropolitanas, el uso de variables objetivas parece más adecuado que la interpretación de estudios de percepción o de opinión, por la dificultad que implica controlar la influencia de factores culturales, de aspiraciones o expectativas.

\section{Diseño metodológico}

Para comparar los cambios en calidad de vida en las áreas metropolitanas principales ${ }^{15}$ entre la década de 2002-2012 se utilizó como métrica el Índice de Calidad de Vida Urbana (ICVU) y el uso de sistemas de información geográfica para comparar y descifrar patrones y tendencias. El ICVU se construyó mediante una revisión exhaustiva de variados indicadores diseñados y/o aplicados por entidades nacionales e internacionales en materia de la calidad de vida, tanto aquellos construidos sobre la base de variables objetivas como subjetivas. El carácter multidimensional de la calidad de vida urbana se estableció analizando la metodología y los resultados de la Encuesta de Percepción

15 Ver nota 7. case an intertemporal analysis of quality of life in metropolitan areas is needed, the use of objective variables seems to be more suitable than the interpretation of studies on perception or opinion due to the difficulty of controlling the influence of cultural, aspiration or expectation factors.

\section{Methodological Design}

The Urban Quality of Life Index (UQLI) ${ }^{15}$ was used to compare the quality of life changes in the main metropolitan areas during the 20022012 period and geographical information systems were used to collate and decipher patterns and trends. The UQLI was developed by means of a comprehensive review of different indicators designed and applied by national and international entities devoted to quality of life issues; these include those built upon objective and subjective variables. The multidimensional nature of urban quality of life was established through the analysis of the methodology and findings of the Perception Survey on Urban Quality of

15 Please refer to note 2 
sobre Calidad de Vida Urbana (EPCVU) ${ }^{16}$ del Ministerio de Vivienda y Urbanismo (MINVU) y de otros indicadores internacionales como el "Better Life Index"17 desarrollado por la Organización para la Coperación y el Desarrollo Económico (OCDE, 2011), el "The Economist Intelligence Unit"18 del diario The Economist, el Índice Mastercard de Mercados Emergentes 2008 por Mastercard ${ }^{19}$ y el "Quality of Living ranking highlights - Global 2011" por MERCER ${ }^{20}$. Todos estos índices son valiosos instrumentos para conocer y comparar los impactos sobre el medio urbano y sus consecuencias en la calidad de vida de quienes habitan esos territorios.

No obstante, a escala comunal y metropolitana solo existe en el país la aproximación que tiene la EPCVU que, sin desmerecer su aporte desde los estudios subjetivos, no define con claridad cuál es el ámbito donde existe una situación favorable o desfavorable asociada a la acción pública y/o privada y tampoco cubre el período en estudio. En el caso de los indicadores internacionales, estos no se pueden aplicar a ciudades fuera del Gran Santiago

16 Encuesta de Percepción sobre la Calidad de Vida Urbana (EPCVU), la cual se aplicó por primera vez el año 2007 y luego el año 2011, a 103 centros urbanos del país. La metodología en detalle se puede ver en: http://www.ine.cl/canales/chile_estadistico/estadisticas sociales culturales/encuesta tiempo libre_2007/metodologia/informe_metodologico_calidad_de_ vida_urbana.pdf

17 Ver en http://oecdbetterlifeindex.org/

18 Ver en http://www.economist.com/node/21016172

19 Ver en www.mastercardworldwide.com/insights

20 Ver en http://www.mercer.com/qualityofliving

26 revista invi № 77 / Mayo 2013 / Volumen № 28: 17-66
Life (PSUQL) $)^{16}$, conducted by the Ministry of Housing and Urban Development (MINVU), and international indicators such as the "Better Life Index"17, developed by the Organization for Economic Co-operation and Development (OECD, 2011); The Economist Intelligence Unit ${ }^{18}$, developed by The Economist; the Emerging Markets Index 2008, compiled by MasterCard ${ }^{19}$; and the Quality of Living Ranking Highlights Global 2011, developed by MERCER ${ }^{20}$. All these indicators are valuable instruments to know and compare the impacts on the urban environment and the effects on the quality of life of those who inhabit these areas.

The PSUQL is the only study at communal and metropolitan level available in the country; however, without detracting from its contribution from subjective studies, this survey does not clearly identify the sphere in which favorable or unfavorable conditions are related to public or

16 Perception Survey on Urban Quality of Life (PSUQL), which was first conducted in 2007 and then in 2011 on 103 urban centers of the country. Further details of the methodology used in this survey is available at http://www.ine.cl/canales/chile estadistico/estadisticas_sociales_culturales/encuesta tiempo_libre_2007/metodologia/informe_metodologico_ calidad_de_vida_urbana.pdf

17 Please refer to http://oecdbetterlifeindex.org/

18 Please refer to http://www.economist.com/node/21016172

19 Please refer to www.mastercardworldwide.com/insights

20 Please refer to http://www.mercer.com/qualityofliving 
y además tienen un sesgo, ya que en el caso de los índices Mastercard y el índice calculado por MERCER, se orientan a cuestiones relativas al potencial económico y de negocios de las ciudades. Por tal motivo, la opción metodológica fue construir un indicador solo en base a variables objetivas, en el entendido que este podría aportar resultados que pudiesen entregar orientaciones más precisas a los tomadores de decisiones sobre dónde se debe poner el acento en materia de inversión pública y privada a futuro. Esto con el propósito tanto de corregir desequilibrios entre comunas y ciudades, como de potenciar sus estrategias de desarrollo en el sentido integral del término.

El ICVU se construyó sobre la base de 33 variables seleccionadas de entre un conjunto que incluía más de cien. Usando el conocimiento experto de un grupo de investigación interdisciplinario ampliado, se seleccionaron estas variables considerando cuatro condicionantes a escala comunal: pertinencia $^{21}$, representatividad ${ }^{22}$, cobertura $^{23}$ y un nivel de actualización que no superara los tres años. Las variables seleccionadas se distribuyeron en seis ámbitos de la calidad de vida reconocibles y

21 Significa que la variable fuera atribuible a una condición de esta comuna.

22 Significa que la variable tenga una representación estadística significante en la comuna.

23 Significa que la variable cubriera todas las comunas del estudio. private actions and neither provides the period of study. As for the international indicators, they are biased and cannot be applied to areas other than Greater Santiago, since the MasterCard and MERCER indicators are oriented towards issues related to the economic and business potential of cities. For this reason, the methodological option of this research was the design of an indicator based solely on objective variables, as it could provide policy makers with more accurate directions on how to guide future public and private investments. The aim is to correct inequality among municipalities and cities and promote development strategies in the integral sense of the term.

The UQLI was built upon the basis of thirty three variables chosen from a set that included more than a hundred possible variables. These were selected by using the expert knowledge of an interdisciplinary research team and considering four conditioning factors at communal scale: pertinence $^{21}$, representation ${ }^{22}$, coverage $^{23}$ and an update level not exceeding three years. The chosen variables were distributed among six recognizable quality of life spheres and adapted

21 It means that the variable is attributable to a condition of this municipality.

22 It means that the variable has an important statistical representation within the municipality.

23 It means that the variable covers all of the analyzed municipalities. 
adaptados a partir de la revisión de los indicadores nacionales e internacionales señalados:

- Condición Laboral (CL), referido a variables que miden las facilidades de acceso al mercado laboral, ingresos, capacitaciones, desarrollo profesional y protección social de los residentes.

- Ambiente de Negocios (AN), referido a variables económicas manifiestas que permitan corroborar que la ciudad y/o comuna es un medio urbano favorable para la generación de inversiones privadas y/o emprendimientos por cuenta propia.

- Condiciones Socio Culturales (CS), referido a la medición de variables relativas al nivel de participación de la población en organizaciones sociales, así como a los niveles de seguridad y educación que afectan la formación de capital social.

- Conectividad y Movilidad (CM), referido a la medición de variables relacionadas con las condiciones de la infraestructura de conectividad, movilidad y seguridad vial de la población residente.

- Salud y Medio Ambiente (SM), referido a la medición de condiciones de salud de la población en relación a enfermedades que presentan una mayor correlación con las condiciones ambientales y su medio antrópico. according to the revision of the aforementioned national and international indicators:

- Work Status (WS), it refers to variables that measure the ease of access to the job market, income, training, professional development and social protection of residents.

- Business Environment (BE), it refers to evident economic variables that make it possible to certify that the city or municipality is a favorable urban environment for private investment or personal business ventures.

- Sociocultural Conditions (SC), it refers to the measurement of variables related to the participation level of the population in social organizations and the security and education levels that affect the generation of social capital.

- Connectivity and Mobility (CM), it refers to the measurement of variables related to the connectivity, mobility and road safety infrastructural conditions of residents.

- Health and Environment (HE), it refers to the measurement of the health conditions of the population in relation to diseases with strong correlation with environmental conditions and anthropogenic spaces. 
- Vivienda y Entorno (VE), referido a variables que dan cuenta de la calidad de la vivienda, nivel de hacinamiento e inversión en el espacio público más próximo para sus residentes.

Para generar un ranking por ámbitos y determinar el ICVU por comuna y ciudad metropolitana, se utilizó la técnica de Análisis de Componentes Principales $(\mathrm{ACP})^{24}$, que en combinación con el conocimiento experto seleccionó un subconjunto de variables (16 para el ICVU 2002 y 17 para el ICVU 2012). Luego se procedió a una normalización de las variables seleccionadas por el ACP para llevarlas a una escala en el rango 0-100, que permitiera comparar variables medidas en unidades muy disímiles y para calcular promedios comparables entre ámbitos y comunas. Esto se aplicó a 69 comunas urbanas, las que representan aproximadamente el $70 \%$ de la población del país, incluyendo todas las capitales regionales y/o comunas de las áreas metropolitanas principales reconocidas o en proceso de conformación. Adicionalmente, para este estudio se aplicaron ponderadores por ámbito a escala comunal y a escala metropolitana, a partir de los resultados obtenidos de una encuesta aplicada a 50 expertos calificados (57\% extranjeros y $43 \%$ nacionales) que trabajan

24 El ACP es una técnica de análisis multivariado que extrae y prioriza información desde grandes conjuntos de datos o con muchas variables. El ACP tiene como objetivo la re-expresión de un conjunto de datos con $k$ variables sobre la base de un nuevo conjunto de $p$ variables (con $p$ mucho menor que $k$ ), que son una combinación y proyección lineal de las variables originales.
- Housing and Living Environment (HLE), it refers to variables related to the quality of housing, overcrowding levels and investment in the immediate public space of residents.

The Principal Component Analysis (PCA $)^{24}$ was used to rank the different spheres and determine the UQLI per municipality and metropolitan city; in combination with expertise, a subset of variables was chosen (16 for the 2002 UQLI and 17 for the 2012 UQLI.) Then, these variables were standardized to a 0-100 scale in order to contrast values measured in different units and calculate comparable averages between areas and municipalities. This procedure was applied to 69 urban municipalities, which represented nearly $70 \%$ of the total population of the country, including all regional capitals or municipalities belonging to recognized or developing main metropolitan areas. In addition, this study applied weighting factors per area at both communal and metropolitan levels according to the findings of a survey of 50 qualified experts (57\% from abroad and 43\% from Chile) working in the fields of teaching, research and international consultancy

24 The PCA is a multivariate analysis technique that extracts and polarizes information from large datasets. The aim of the PCA is to restate datasets with $k$ variables on the basis of a new group of $p$ variables (with $p$ being much lower than $k$ ), which constitute a linear combination and projection of the original variables. 
directamente en el campo de la docencia, investigación y consultoría internacional en materias afines. Los ponderadores obtenidos por ámbitos a estas dos escalas de territorio se pueden observar en la Tabla 1.

Finalmente, una vez calculado el indicador por cada uno de los seis ámbitos, se ponderaron estos resultados para obtener el ICVU para cada año para todas las comunas del estudio. Así, se confeccionó un ranking del ICVU y un ranking por ámbito para cada área metropolitana, así como también se construyó la cartografía correspondiente a escala comunal. in related matters. Table 1 shows these weighting factors per area derived from the two scales of territory.

Finally, the indicators of these six areas were weighted to obtain the corresponding UQLI score for every year for all of the analyzed municipalities. Thus, a UQLI ranked list and a classification by sphere were prepared for each metropolitan area; likewise, a corresponding mapping at communal level was also elaborated.

TABLA 1: PONDERACIÓN DE ÁMBITOS DE CALIDAD DE VIDA URBANA (\%).

\begin{tabular}{|c|c|c|c|c|c|}
\hline \multicolumn{6}{|c|}{ Ponderación Escala Local } \\
\hline CL & AN & CS & CM & SM & VE \\
\hline $9,4 \%$ & $16,4 \%$ & $17,4 \%$ & $9,1 \%$ & $18,5 \%$ & $29,1 \%$ \\
\hline \multicolumn{6}{|c|}{ Ponderación Escala Metropolitana } \\
\hline $\mathbf{C L}$ & AN & CS & CM & SM & VE \\
\hline $9,7 \%$ & $17,1 \%$ & $17,2 \%$ & $9,7 \%$ & $18,8 \%$ & $27,6 \%$ \\
\hline
\end{tabular}

Fuente: elaboración propia, según Encuesta sobre Calidad de Vida Urbana NEM-IEUT, 2012.

TABLE 1: WEIGHTING OF SPHERES OF URBAN OUALITY OF LIFE.

\begin{tabular}{|c|c|c|c|c|c|}
\hline WS & BE & SC & CM & HE & HLE \\
\hline $9.4 \%$ & $16.4 \%$ & $17.4 \%$ & $9.1 \%$ & $18.5 \%$ & $29.1 \%$ \\
\hline \multicolumn{6}{|c|}{ Metropolitan Scale Weighting } \\
\hline WS & BE & SC & CM & HE & HLE \\
\hline $9.7 \%$ & $17.1 \%$ & $17.2 \%$ & $9.7 \%$ & $18.8 \%$ & $27.6 \%$ \\
\hline
\end{tabular}

Source: prepared by authors based on the Urban Quality of Life Index NEM-IEUT, 2012. 


\section{Resultados ICVU 2012}

En cuanto a los resultados obtenidos para el año 2012, la Tabla 2 muestra las comunas urbanas con un ICVU mayor al promedio nacional $(42,8)$. Entre las diez primeras comunas urbanas que alcanzan un mayor ICVU, siete pertenecen al Gran Santiago, de mayor a menor: Vitacura, Las Condes, Providencia, Santiago, Lo Barnechea, Nuñoa y La Reina, que no solo ocupan los siete primeros lugares del ranking, sino que también se concentran todas en el sector nororiente de Santiago. Luego se sitúan las comunas de Punta Arenas (lugar 8), Concón (9) y La Serena (10).

En contraposición, al observar la Tabla 3 ésta presenta un ranking de aquellas comunas que obtuvieron un ICVU inferior al promedio nacional, se puede constatar que de las diez comunas con menor ICVU, donde siete son también del Gran Santiago, de menor a mayor: San Ramón, La Pintana, Lo Espejo, El Bosque, Pedro Aguirre Cerda, La Granja y San Bernardo. Respecto a las comunas fuera del Gran Santiago, las con menor ICVU 2012 son las de Lota (66), San Antonio (64) y Alto Hospicio (61). En consecuencia, se puede afirmar que 28 de 69 comunas urbanas consignadas en este estudio ofrecen una calidad de vida superior al promedio nacional, 13 del Gran Santiago y 15 de regiones, incluyendo todas las capitales

\section{UOLI Results}

As for the 2012 results, Table 2 shows the urban municipalities with UQLI scores above the national average (42.8.) Seven out of the top ten urban municipalities that achieved higher UQLI scores belong to Greater Santiago, sorted from higher to lower, they are: Vitacura, Las Condes, Providencia, Santiago, Lo Barnechea, Nuñoa and La Reina; these do not only hold the first seven places in this list, but are also located in the north-east area of Santiago. The top table is completed by Punta Arenas (ranked 8th), Concón (ranked 9th) and La Serena (ranked 10th.)

In contrast, Table 3 shows those municipalities with a UQLI score below the national average; from this list, seven out of ten municipalities also belong to Greater Santiago, sorted from lower to higher, they are: San Ramón, La Pintana, Lo Espejo, El Bosque, Pedro Aguirre Cerda, La Granja and San Bernardo. This table with lower UQLI 2012 is completed by municipalities located outside Greater Santiago; these are Lota (ranked 66th), San Antonio (ranked 64th) and Alto Hospicio (ranked 61st.) Thus, it is clear that 28 out of the 69 urban municipalities included in this research offer quality of life that exceed the national average; from this figure, 13 municipalities are located in Greater Santiago and 15 in the rest of the regions, 
TABLA 2: COMUNAS CON ICVU 2012 MAYOR AL PROMEDIO NACIONAL.

\begin{tabular}{|c|c|c|c|c|c|c|c|c|}
\hline POSICIÓN & COMUNA & $\mathrm{CL}$ & AN & CS & $\mathrm{CM}$ & SM & VE & ICVU \\
\hline 1 & Vitacura & 67,4 & 65,8 & 86,8 & 70,5 & 95,9 & 61,4 & 74,5 \\
\hline 2 & Las Condes & 72,5 & 60,2 & 61,9 & 88,5 & 82,9 & 72,3 & 72,1 \\
\hline 3 & Providencia & 87,0 & 45,9 & 73,8 & 87,2 & 54,3 & 76,2 & 68,9 \\
\hline 4 & Santiago & 78,9 & 57,8 & 39,4 & 31,5 & 64,4 & 94,1 & 66,1 \\
\hline 5 & Lo Barnechea & 38,7 & 42,6 & 45,8 & 82,4 & 78,5 & 77,9 & 63,5 \\
\hline 6 & Ñuñoa & 53,6 & 40,3 & 50,7 & 52,4 & 72,5 & 61,1 & 56,6 \\
\hline 7 & La Reina & 66,5 & 47,7 & 51,6 & 80,8 & 58,9 & 51,6 & 56,5 \\
\hline 8 & Punta Arenas & 52,9 & 24,5 & 47,8 & 34,6 & 60,7 & 61,1 & 49,6 \\
\hline 9 & Concón & 26,4 & 38,8 & 44,0 & 65,6 & 73,8 & 44,9 & 49,4 \\
\hline 10 & La Serena & 25,8 & 32,6 & 54,4 & 45,6 & 58,6 & 57,5 & 49,1 \\
\hline 11 & Maipú & 37,3 & 16,6 & 66,1 & 82,0 & 58,9 & 42,0 & 48,5 \\
\hline 12 & Talcahuano & 29,4 & 22,2 & 49,7 & 73,2 & 62,8 & 51,1 & 48,3 \\
\hline 13 & Machalí & 68,1 & 43,2 & 31,8 & 48,8 & 69,4 & 40,5 & 48,2 \\
\hline 14 & San Pedro de la Paz & 32,0 & 35,0 & 39,0 & 54,4 & 57,1 & 56,6 & 47,7 \\
\hline 15 & Puerto Varas & 25,3 & 40,6 & 49,0 & 55,9 & 52,5 & 51,2 & 47,4 \\
\hline 16 & Concepción & 33,1 & 59,8 & 59,6 & 50,7 & 30,9 & 46,2 & 47,2 \\
\hline 17 & Cerrillos & 31,7 & 22,6 & 26,4 & 59,2 & 69,5 & 59,4 & 47,0 \\
\hline 18 & Valdivia & 26,0 & 24,5 & 56,8 & 51,4 & 58,6 & 49,4 & 46,4 \\
\hline 19 & Estación Central & 32,7 & 29,3 & 26,9 & 63,9 & 64,6 & 53,3 & 46,0 \\
\hline 20 & Antofagasta & 43,2 & 41,0 & 32,5 & 66,7 & 57,0 & 41,2 & 45,2 \\
\hline 21 & Iquique & 17,0 & 44,9 & 32,2 & 75,4 & 59,3 & 42,4 & 44,9 \\
\hline 22 & Copiapó & 40,5 & 31,1 & 47,6 & 67,0 & 66,6 & 30,6 & 44,7 \\
\hline 23 & Rancagua & 43,2 & 26,9 & 42,1 & 49,2 & 54,9 & 48,3 & 44,6 \\
\hline 24 & Viña del Mar & 33,5 & 23,3 & 37,4 & 68,6 & 48,1 & 51,3 & 43,7 \\
\hline 25 & Huechuraba & 17,8 & 21,6 & 31,4 & 65,4 & 52,9 & 56,9 & 43,1 \\
\hline 26 & San Miguel & 48,9 & 20,2 & 43,1 & 78,1 & 36,4 & 47,0 & 43,0 \\
\hline 27 & Macul & 22,0 & 19,3 & 40,0 & 73,9 & 53,8 & 48,1 & 43,0 \\
\hline \multirow[t]{2}{*}{28} & Hualpén & 29,6 & 22,5 & 34,8 & 62,0 & 48,4 & 53,8 & 42,9 \\
\hline & PROMEDIO & 32,7 & 27,1 & 40,1 & 60,3 & 52,6 & 44,6 & 42,8 \\
\hline
\end{tabular}

Fuente: elaboración propia, 2012. 
TABLE 2: MUNICIPALITIES WITH A 2012 UQLI SCORE ABOVE THE NATIONAL AVERAGE.

\begin{tabular}{|c|c|c|c|c|c|c|c|c|}
\hline PLACE & MUNICIPALITY & WS & $\mathrm{BE}$ & SC & CM & HE & HLE & UQLI \\
\hline 1 & Vitacura & 67.4 & 65.8 & 86.8 & 70.5 & 95.9 & 61.4 & 74.5 \\
\hline 2 & Las Condes & 72.5 & 60.2 & 61.9 & 88.5 & 82.9 & 72.3 & 72.1 \\
\hline 3 & Providencia & 87.0 & 45.9 & 73.8 & 87.2 & 54.3 & 76.2 & 68.9 \\
\hline 4 & Santiago & 78.9 & 57.8 & 39.4 & 31.5 & 64.4 & 94.1 & 66.1 \\
\hline 5 & Lo Barnechea & 38.7 & 42.6 & 45.8 & 82.4 & 78.5 & 77.9 & 63.5 \\
\hline 6 & Ñuñoa & 53.6 & 40.3 & 50.7 & 52.4 & 72.5 & 61.1 & 56.6 \\
\hline 7 & La Reina & 66.5 & 47.7 & 51.6 & 80.8 & 58.9 & 51.6 & 56.5 \\
\hline 8 & Punta Arenas & 52.9 & 24.5 & 47.8 & 34.6 & 60.7 & 61.1 & 49.6 \\
\hline 9 & Concón & 26.4 & 38.8 & 44.0 & 65.6 & 73.8 & 44.9 & 49.4 \\
\hline 10 & La Serena & 25.8 & 32.6 & 54.4 & 45.6 & 58.6 & 57.5 & 49.1 \\
\hline 11 & Maipú & 37.3 & 16.6 & 66.1 & 82.0 & 58.9 & 42.0 & 48.5 \\
\hline 12 & Talcahuano & 29.4 & 22.2 & 49.7 & 73.2 & 62.8 & 51.1 & 48.3 \\
\hline 13 & Machalí & 68.1 & 43.2 & 31.8 & 48.8 & 69.4 & 40.5 & 48.2 \\
\hline 14 & San Pedro de la Paz & 32.0 & 35.0 & 39.0 & 54.4 & 57.1 & 56.6 & 47.7 \\
\hline 15 & Puerto Varas & 25.3 & 40.6 & 49.0 & 55.9 & 52.5 & 51.2 & 47.4 \\
\hline 16 & Concepción & 33.1 & 59.8 & 59.6 & 50.7 & 30.9 & 46.2 & 47.2 \\
\hline 17 & Cerrillos & 31.7 & 22.6 & 26.4 & 59.2 & 69.5 & 59.4 & 47.0 \\
\hline 18 & Valdivia & 26.0 & 24.5 & 56.8 & 51.4 & 58.6 & 49.4 & 46.4 \\
\hline 19 & Estación Central & 32.7 & 29.3 & 26.9 & 63.9 & 64.6 & 53.3 & 46.0 \\
\hline 20 & Antofagasta & 43.2 & 41.0 & 32.5 & 66.7 & 57.0 & 41.2 & 45.2 \\
\hline 21 & Iquique & 17.0 & 44.9 & 32.2 & 75.4 & 59.3 & 42.4 & 44.9 \\
\hline 22 & Copiapó & 40.5 & 31.1 & 47.6 & 67.0 & 66.6 & 30.6 & 44.7 \\
\hline 23 & Rancagua & 43.2 & 26.9 & 42.1 & 49.2 & 54.9 & 48.3 & 44.6 \\
\hline 24 & Viña del Mar & 33.5 & 23.3 & 37.4 & 68.6 & 48.1 & 51.3 & 43.7 \\
\hline 25 & Huechuraba & 17.8 & 21.6 & 31.4 & 65.4 & 52.9 & 56.9 & 43.1 \\
\hline 26 & San Miguel & 48.9 & 20.2 & 43.1 & 78.1 & 36.4 & 47.0 & 43.0 \\
\hline 27 & Macul & 22.0 & 19.3 & 40.0 & 73.9 & 53.8 & 48.1 & 43.0 \\
\hline \multirow[t]{2}{*}{28} & Hualpén & 29.6 & 22.5 & 34.8 & 62.0 & 48.4 & 53.8 & 42.9 \\
\hline & AVERAGE & 32.7 & 27.1 & 40.1 & 60.3 & 52.6 & 44.6 & 42.8 \\
\hline
\end{tabular}

Source: prepared by authors, 2012 
TABLA 3: COMUNAS CON ICVU 2012 MENOR AL PROMEDIO NACIONAL.

\begin{tabular}{|c|c|c|c|c|c|c|c|c|}
\hline POSICIÓN & COMUNA & $\mathrm{CL}$ & AN & CS & $\mathrm{CM}$ & SM & VE & ICVU \\
\hline 29 & Quilicura & 32,2 & 20,1 & 30,4 & 74,2 & 60,0 & 45,2 & 42,7 \\
\hline 30 & Chiguayante & 29,8 & 21,1 & 39,3 & 78,9 & 60,5 & 37,7 & 42,6 \\
\hline 31 & La Cisterna & 31,5 & 21,4 & 39,2 & 58,7 & 64,2 & 40,7 & 42,5 \\
\hline 32 & Temuco & 16,3 & 22,8 & 49,3 & 50,1 & 58,1 & 44,8 & 42,3 \\
\hline 33 & Osorno & 35,8 & 26,6 & 48,6 & 47,5 & 30,3 & 53,8 & 41,9 \\
\hline 34 & Coquimbo & 25,7 & 27,8 & 48,4 & 58,8 & 43,7 & 44,3 & 41,8 \\
\hline 35 & Coronel & 26,3 & 40,1 & 37,7 & 54,5 & 53,4 & 37,8 & 41,6 \\
\hline 36 & Conchalí & 34,5 & 20,5 & 33,8 & 68,0 & 50,7 & 45,5 & 41,4 \\
\hline 37 & Renca & 22,9 & 34,9 & 32,6 & 72,0 & 45,0 & 43,5 & 41,2 \\
\hline 38 & San Joaquín & 36,8 & 24,1 & 41,4 & 56,7 & 39,2 & 46,8 & 40,8 \\
\hline 39 & La Florida & 35,7 & 27,1 & 35,2 & 69,6 & 44,3 & 41,7 & 40,7 \\
\hline 40 & Peñalolén & 27,7 & 26,1 & 30,4 & 75,1 & 51,2 & 40,7 & 40,5 \\
\hline 41 & Independencia & 38,5 & 33,1 & 21,1 & 68,0 & 53,3 & 38,8 & 40,2 \\
\hline 42 & Villa Alemana & 24,7 & 11,5 & 44,8 & 69,4 & 65,3 & 32,4 & 40,0 \\
\hline 43 & Pudahuel & 28,1 & 26,2 & 36,4 & 63,4 & 46,8 & 41,0 & 39,8 \\
\hline 44 & Quilpué & 29,6 & 13,4 & 38,8 & 51,4 & 63,1 & 37,9 & 39,2 \\
\hline 45 & Arica & 31,6 & 22,3 & 31,1 & 60,5 & 51,0 & 38,2 & 38,2 \\
\hline 46 & Chillán Viejo & 23,8 & 31,0 & 46,9 & 39,8 & 47,0 & 34,7 & 38,0 \\
\hline 47 & Talca & 13,5 & 29,2 & 43,4 & 51,7 & 35,9 & 44,5 & 38,0 \\
\hline 48 & Penco & 29,7 & 18,6 & 38,0 & 53,2 & 59,6 & 32,9 & 38,0 \\
\hline 49 & Recoleta & 34,2 & 14,7 & 25,9 & 64,0 & 49,2 & 42,6 & 37,6 \\
\hline 50 & Puente Alto & 31,3 & 21,1 & 36,0 & 70,7 & 31,6 & 41,3 & 37,1 \\
\hline 51 & Coyhaique & 46,5 & 40,0 & 39,6 & 42,0 & 54,1 & 17,1 & 36,8 \\
\hline 52 & Tomé & 24,8 & 18,9 & 55,1 & 53,0 & 44,0 & 29,7 & 36,7 \\
\hline 53 & Valparaíso & 23,0 & 23,2 & 37,3 & 61,7 & 49,4 & 31,8 & 36,6 \\
\hline 54 & Chillán & 24,1 & 28,2 & 49,0 & 23,1 & 42,8 & 36,4 & 36,1 \\
\hline 55 & Lo Prado & 27,2 & 15,6 & 33,7 & 58,4 & 37,5 & 40,6 & 35,2 \\
\hline 56 & Puerto Montt & 28,2 & 15,7 & 40,6 & 45,7 & 39,7 & 36,3 & 34,5 \\
\hline 57 & Padre las Casas & 10,8 & 2,0 & 51,5 & 48,0 & 60,1 & 28,8 & 34,3 \\
\hline
\end{tabular}




\begin{tabular}{lllllllll}
\hline POSICIÓN & COMUNA & CL & AN & CS & CM & SM & VE & ICVU \\
\hline $\mathbf{5 8}$ & Quinta Normal & 32,8 & 28,6 & 22,9 & 38,2 & 45,4 & 36,1 & $\mathbf{3 4 , 2}$ \\
\hline $\mathbf{5 9}$ & Cerro Navia & 12,4 & 15,3 & 33,3 & 57,7 & 48,1 & 36,0 & $\mathbf{3 4 , 2}$ \\
\hline $\mathbf{6 0}$ & San Bernardo & 17,3 & 24,9 & 29,1 & 67,6 & 32,0 & 37,9 & $\mathbf{3 4 , 0}$ \\
\hline $\mathbf{6 1}$ & Alto Hospicio & 18,2 & 31,7 & 20,6 & 39,9 & 52,9 & 32,6 & $\mathbf{3 3 , 5}$ \\
\hline $\mathbf{6 2}$ & La Granja & 7,0 & 17,2 & 24,9 & 75,4 & 46,9 & 33,4 & $\mathbf{3 3 , 2}$ \\
\hline $\mathbf{6 3}$ & Pedro Aguirre Cerda & 26,5 & 9,6 & 35,1 & 76,0 & 25,8 & 36,1 & $\mathbf{3 2 , 4}$ \\
\hline $\mathbf{6 4}$ & San Antonio & 18,4 & 16,6 & 28,6 & 24,6 & 49,8 & 38,8 & $\mathbf{3 2 , 3}$ \\
\hline $\mathbf{6 5}$ & El Bosque & 27,4 & 11,8 & 27,9 & 66,9 & 41,8 & 30,2 & $\mathbf{3 2 , 1}$ \\
\hline $\mathbf{6 6}$ & Lota & 17,5 & 12,9 & 48,9 & 48,3 & 29,0 & 33,8 & $\mathbf{3 2 , 0}$ \\
\hline $\mathbf{6 7}$ & Lo Espejo & 25,7 & 13,4 & 17,3 & 65,5 & 40,9 & 34,7 & $\mathbf{3 1 , 4}$ \\
\hline $\mathbf{6 9}$ & La Pintana & 29,4 & 8,7 & 15,4 & 61,7 & 42,8 & 34,3 & $\mathbf{3 0 , 5}$ \\
\hline & San Ramón & 16,6 & 0,4 & 22,9 & 68,4 & 40,0 & 36,0 & $\mathbf{2 9 , 8}$ \\
\hline
\end{tabular}

Fuente: elaboración propia, 2012.

TABLE 3: MUNICIPALITIES WITH A 2012 UOLI SCOREBELOW THE NATIONAL AVERAGE.

\begin{tabular}{lllllllll}
\hline PLACE & MUNICIPALITY & WS & BE & SC & CM & HE & HLE & UQLI \\
\hline $\mathbf{2 9}$ & Quilicura & 32.2 & 20.1 & 30.4 & 74.2 & 60.0 & 45.2 & $\mathbf{4 2 . 7}$ \\
\hline $\mathbf{3 0}$ & Chiguayante & 29.8 & 21.1 & 39.3 & 78.9 & 60.5 & 37.7 & $\mathbf{4 2 . 6}$ \\
\hline $\mathbf{3 1}$ & La Cisterna & 31.5 & 21.4 & 39.2 & 58.7 & 64.2 & 40.7 & $\mathbf{4 2 . 5}$ \\
\hline $\mathbf{3 2}$ & Temuco & 16.3 & 22.8 & 49.3 & 50.1 & 58.1 & 44.8 & $\mathbf{4 2 . 3}$ \\
\hline $\mathbf{3 3}$ & Osorno & 35.8 & 26.6 & 48.6 & 47.5 & 30.3 & 53.8 & $\mathbf{4 1 . 9}$ \\
\hline $\mathbf{3 4}$ & Coquimbo & 25.7 & 27.8 & 48.4 & 58.8 & 43.7 & 44.3 & $\mathbf{4 1 . 8}$ \\
\hline $\mathbf{3 5}$ & Coronel & 26.3 & 40.1 & 37.7 & 54.5 & 53.4 & 37.8 & $\mathbf{4 1 . 6}$ \\
\hline $\mathbf{3 6}$ & Conchalí & 34.5 & 20.5 & 33.8 & 68.0 & 50.7 & 45.5 & $\mathbf{4 1 . 4}$ \\
\hline $\mathbf{3 7}$ & Renca & 22.9 & 34.9 & 32.6 & 72.0 & 45.0 & 43.5 & $\mathbf{4 1 . 2}$ \\
\hline $\mathbf{3 8}$ & San Joaquín & 36.8 & 24.1 & 41.4 & 56.7 & 39.2 & 46.8 & $\mathbf{4 0 . 8}$ \\
\hline $\mathbf{3 9}$ & La Florida & 35.7 & 27.1 & 35.2 & 69.6 & 44.3 & 41.7 & $\mathbf{4 0 . 7}$ \\
\hline $\mathbf{4 0}$ & Peñalolén & 27.7 & 26.1 & 30.4 & 75.1 & 51.2 & 40.7 & $\mathbf{4 0 . 5}$ \\
\hline & & & & & & & &
\end{tabular}




\begin{tabular}{|c|c|c|c|c|c|c|c|c|}
\hline PLACE & MUNICIPALITY & WS & $\mathrm{BE}$ & SC & $\mathrm{CM}$ & $\mathrm{HE}$ & HLE & UQLI \\
\hline 41 & Independencia & 38.5 & 33.1 & 21.1 & 68.0 & 53.3 & 38.8 & 40.2 \\
\hline 42 & Villa Alemana & 24.7 & 11.5 & 44.8 & 69.4 & 65.3 & 32.4 & 40.0 \\
\hline 43 & Pudahuel & 28.1 & 26.2 & 36.4 & 63.4 & 46.8 & 41.0 & 39.8 \\
\hline 44 & Quilpué & 29.6 & 13.4 & 38.8 & 51.4 & 63.1 & 37.9 & 39.2 \\
\hline 45 & Arica & 31.6 & 22.3 & 31.1 & 60.5 & 51.0 & 38.2 & 38.2 \\
\hline 46 & Chillán Viejo & 23.8 & 31.0 & 46.9 & 39.8 & 47.0 & 34.7 & 38.0 \\
\hline 47 & Talca & 13.5 & 29.2 & 43.4 & 51.7 & 35.9 & 44.5 & 380 \\
\hline 48 & Penco & 29.7 & 18.6 & 38.0 & 53.2 & 59.6 & 32.9 & 38.0 \\
\hline 49 & Recoleta & 34.2 & 14.7 & 25.9 & 64.0 & 49.2 & 42.6 & 37.6 \\
\hline 50 & Puente Alto & 31.3 & 21.1 & 36.0 & 70.7 & 31.6 & 41.3 & 37.1 \\
\hline 51 & Coyhaique & 46.5 & 40.0 & 39.6 & 42.0 & 54.1 & 17.1 & 36.8 \\
\hline 52 & Tome & 24.8 & 18.9 & 55.1 & 53.0 & 44.0 & 29.7 & 36.7 \\
\hline 53 & Valparaíso & 23.0 & 23.2 & 37.3 & 61.7 & 49.4 & 31.8 & 36.6 \\
\hline 54 & Chillan & 24.1 & 28.2 & 49.0 & 23.1 & 42.8 & 36.4 & 36.1 \\
\hline 55 & Lo Prado & 27.2 & 15.6 & 33.7 & 58.4 & 37.5 & 40.6 & 35.2 \\
\hline 56 & Puerto Montt & 28.2 & 15.7 & 40.6 & 45.7 & 39.7 & 36.3 & 34.5 \\
\hline 57 & Padre las Casas & 10.8 & 2.0 & 51.5 & 48.0 & 60.1 & 28.8 & 34.3 \\
\hline 58 & Quinta Normal & 32.8 & 28.6 & 22.9 & 38.2 & 45.4 & 36.1 & 34.2 \\
\hline 59 & Cerro Navia & 12.4 & 15.3 & 33.3 & 57.7 & 48.1 & 36.0 & 34.2 \\
\hline 60 & San Bernardo & 17.3 & 24.9 & 29.1 & 67.6 & 32.0 & 37.9 & 34.0 \\
\hline 61 & Alto Hospicio & 18.2 & 31.7 & 20.6 & 39.9 & 52.9 & 32.6 & 33.5 \\
\hline 62 & La Granja & 7.0 & 17.2 & 24.9 & 75.4 & 46.9 & 33.4 & 33.2 \\
\hline 63 & Pedro Aguirre Cerda & 26.5 & 9.6 & 35.1 & 76.0 & 25.8 & 36.1 & 32.4 \\
\hline 64 & San Antonio & 18.4 & 16.6 & 28.6 & 24.6 & 49.8 & 38.8 & 32.3 \\
\hline 65 & El Bosque & 27.4 & 11.8 & 27.9 & 66.9 & 41.8 & 30.2 & 32.1 \\
\hline 66 & Lota & 17.5 & 12.9 & 48.9 & 48.3 & 29.0 & 33.8 & 32.0 \\
\hline 67 & Lo Espejo & 25.7 & 13.4 & 17.3 & 65.5 & 40.9 & 34.7 & 31.4 \\
\hline 68 & La Pintana & 29.4 & 8.7 & 15.4 & 61.7 & 42.8 & 34.3 & 30.5 \\
\hline \multirow[t]{2}{*}{69} & San Ramón & 16.6 & 0.4 & 22.9 & 68.4 & 40.0 & 36.0 & 29.8 \\
\hline & AVERAGE & 32.7 & 27.1 & 40.1 & 60.3 & 52.6 & 44.6 & 42.8 \\
\hline
\end{tabular}

Source: prepared by authors, 2012 
regionales, a excepción de Arica, Valparaíso, Talca, Temuco y Coyhaique.

Ahora, focalizando el análisis en los resultados obtenidos en las tres principales áreas metropolitanas de Chile, Gran Santiago, Gran Valparaíso y Gran Concepción, el ICVU 2012 arroja interesante evidencia de que el desequilibrio es mayor al interior de las áreas metropolitanas que al comparar la situación de calidad de vida urbana entre todas las comunas del estudio. Entonces, para el caso del Gran Santiago se observa en la figura 1 que solo 13 de las 34 comunas superan la media nacional, es decir, equivalente a un 40\% de la población, siendo la media del Gran Santiago $(44,1)$ superior a la media nacional $(42,8)$.

Por su parte, la figura 2 muestra que para el caso del Gran Valparaíso -que comprende la situación de calidad de vida urbana de cinco comunas- la comuna de Concón y la comuna Viña del Mar están por sobre la media nacional $(42,8)$ y la media del Gran Valparaíso $(41,8)$, mientras que Villa Alemana, Quilpué y el propio Valparaíso están por debajo de la media nacional, lo que significa que el $61,7 \%$ de la población de esta área metropolitana tiene un ICVU inferior a la media nacional.

Por último, la situación del Gran Concepción, constituida por nueve comunas, se ve reflejada en la figura 3, que muestra a Talcahuano, San Pedro de la Paz, Concepción y Hualpén por sobre la including all regional capitals with the exception of Arica, Valparaíso, Talca, Temuco and Coyhaique.

By concentrating the analysis on the results obtained from the three main Chilean metropolitan areas: Greater Santiago, Greater Valparaíso and Greater Concepcion, the 2012 UQLI provides evidence that inequality is greater within metropolitan areas than comparing the urban quality of life situation among all of the analyzed municipalities. Thus, Graphic 1 shows that only 13 out of the 34 municipalities of Greater Santiago exceed the national average, that is to say, $40 \%$ of the population; in this sense, the average of Greater Santiago (44.1) is higher than the national average (42.8.).

In the case of Greater Valparaíso -which includes the urban quality of life situation of five municipalitiesgraphic 2 shows that, while Concón and Viña del Mar exceed the national average (42.8) and the average of Greater Valparaíso (41.8), the indicators of Villa Alemana, Quilpué and Valparaíso itself are lower than the national average; this means that $61.7 \%$ of the population of this metropolitan area has a UQLI score below the national average.

As regards the situation of Greater Concepción, which is composed of nine municipalities, graphic 3 shows that while Talcahuano, San Pedro de la Paz, Concepción and Hualpén exceed the national average, the indicators of Chiguayante, Coronel, 
FIGURA 1: RANKING DE COMUNAS DEL GRAN SANTIAGO SEGÚN ICVU 2012.

GRAPHIC 1: RANKED LIST OF MUNICIPALITIES BELONGING TO GREATER SANTIAGO ACCORDING TO THE 2012 UQLI

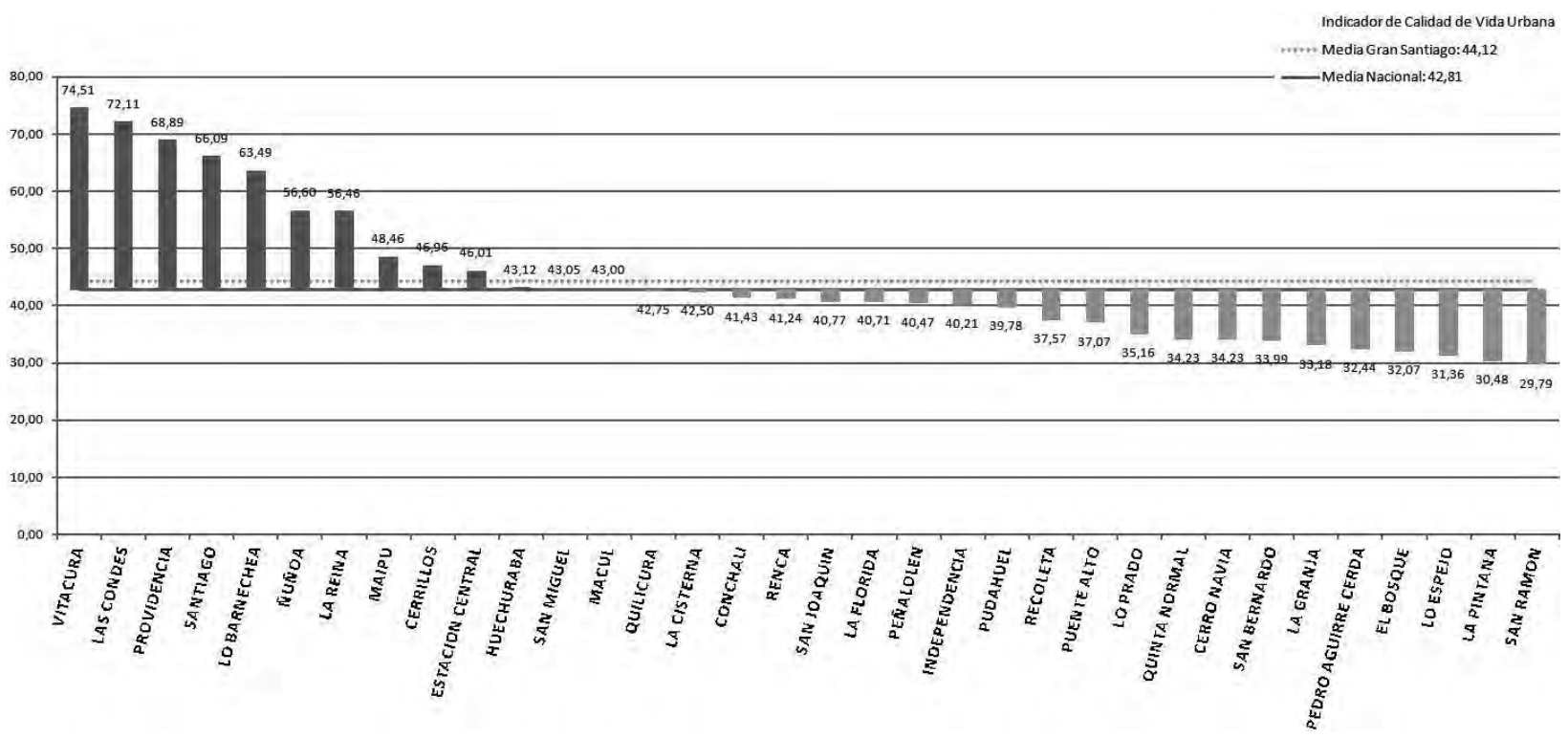

Fuente: elaboración propia, 2012

Source: prepared by authors, 2012 
FIGURA 2: RANKING DE COMUNAS DEL GRAN VALPARAÍSO SEGÚN ICVU 2012.

GRAPHIC 2: RANKED LIST OF MUNICIPALITIES BELONGING TO GREATER VALPARAÍSO ACCORDING TO THE 2012 UQLI

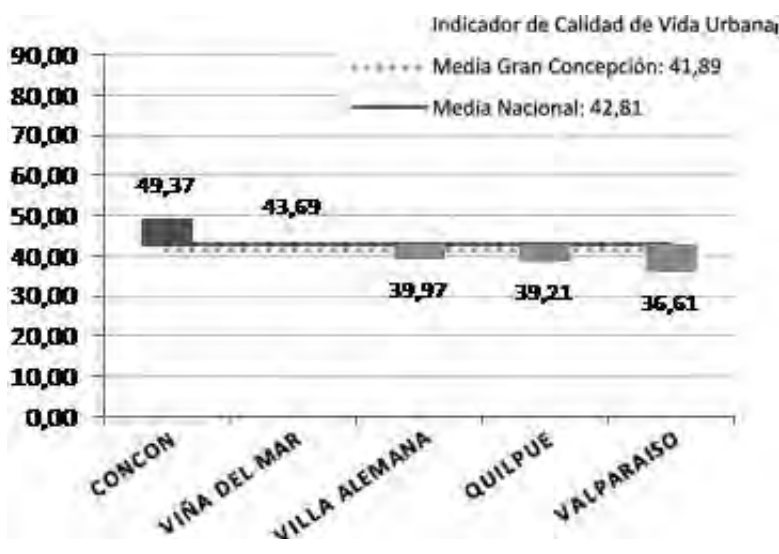

Fuente: elaboración propia, 2012 Source: prepared by authors, 2012

media nacional, mientras que Chiguayante, Coronel, Penco, Tomé y Lota por debajo de la media del Gran Concepción $(41,9)$ y la media nacional $(42,8)$. Esto significa que el 60\% de la población del Gran Concepción tiene un ICVU superior a la media nacional, situación que contrasta totalmente con el Gran Santiago (40\%) y Gran Valparaíso (38,3\%). Esta es una indicación de que Gran Concepción muestra un mayor grado de equidad territorial en términos de calidad de vida urbana.

\section{FIGURA 3: RANKING DE COMUNAS DEL GRAN CONCEPCIÓN SEGÚN ICVU 2012. \\ GRAPHIC 3: RANKED LIST OF MUNICIPALITIES BELONGING TO GREATER CONCEPCIÓN ACCORDING TO THE 2012 UOLI}

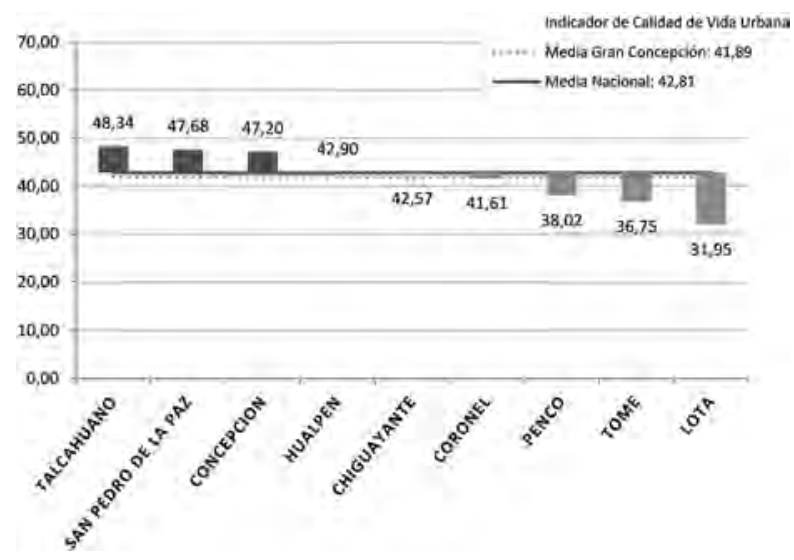

Fuente: elaboración propia, 2012

Source: prepared by authors, 2012

Penco, Tomé and Lota are lower than the average of Greater Concepción (41.9) and the national average (42.8?) This means that $60 \%$ of the population of Greater Concepción enjoys a UQLI score above the national average, a situation that contrasts greatly with the indicators of Greater Santiago (40\%) and Greater Valparaíso (38.3\%.) Such a scenario indicates that Greater Concepción presents high levels of territorial equity in terms of urban quality of life. 


\section{Resultados ICVU 2002}

El ICVU 2002 se calculó para las mismas comunas consignadas en las secciones anteriores, a excepción de las comunas de Alto-Hospicio y Hualpén, que legalmente no estaban creadas a esa fecha. Respecto a las 33 variables que constituyen la base de cálculo del ICVU conforme a la metodología empleada el año 2011 y 2012, se tuvo disponibilidad de información solo para 29 de las 33 variables consignadas, sin que esta situación alterara significativamente las posibilidades de comparación en una década. Finalmente, se deja constancia que para este caso también se utilizaron los ponderadores por ámbitos con los que se calculó el ICVU 2012, conscientes que probablemente de haberse aplicado la encuesta a expertos hace una década, pudiese diferir en algo la distribución de porcentajes.

En cuanto a los resultados obtenidos para el año 2002, la Tabla 4 muestra las comunas urbanas con un ICVU mayor al promedio nacional $(34,5)$, donde entre las diez comunas urbanas que alcanzan un mayor ICVU, ocho son del Gran Santiago, de mayor a menor: Vitacura, Lo Barnechea, Providencia, Las Condes, Santiago, La Reina, Nuñoa y Macul, las primeras ocupando los primeros siete lugares y Macul la posición 9. Solo San Pedro de la Paz (8) y Valdivia (10) están dentro de este grupo selecto de comunas. Así, se puede afirmar que 24 de

\section{UOLI Results}

The 2002 UQLI was estimated for the same municipalities included in the previous sections with the exception of Alto Hospicio and Hualpén, which had not been legally established at that time. As regards the 33 variables composing the calculation basis of the UQLI according to the methodology used for years 2011 and 2012, there was information available from 29 out of 33 variables; this situation did not significantly alter the comparison possibilities over a decade. Finally, the same weighting factors per sphere to calculate the 2012 UQLI were used in this case, bearing in mind that percentage distribution could have been slightly affected if the survey of experts had been conducted 10 years ago.

As for the 2002 results, Table 4 shows the urban municipalities with a UQLI score above the national average (34.5); eight out of the top ten urban municipalities scoring higher UQLI scores belong to Greater Santiago, sorted from higher to lower, they are: Vitacura, Lo Barnechea, Providencia, Las Condes, Santiago, La Reina, Nuñoa, and Macul. The first seven municipalities hold the first seven places in this list and Macul holds the 9th place. Outside Greater Santiago, only San Pedro de la Paz (ranked 8th) and Valdivia (ranked 10th) are included in this selected group of municipalities. 
TABLA 4: COMUNAS CON ICVU 2002 MAYOR AL PROMEDIO NACIONAL.

\begin{tabular}{lllllllll}
\hline POSICIÓN & COMUNA & CL & AN & CS & CM & SM & VE & ICVU \\
\hline $\mathbf{1}$ & Vitacura & 59,0 & 55,7 & 59,3 & 78,0 & 96,5 & 86,5 & $\mathbf{7 5 , 4}$ \\
\hline $\mathbf{2}$ & Lo Barnechea & 35,0 & 52,3 & 46,9 & 85,4 & 86,5 & 79,5 & $\mathbf{6 7 , 2}$ \\
\hline $\mathbf{3}$ & Providencia & 64,5 & 55,0 & 49,3 & 74,9 & 80,9 & 72,3 & $\mathbf{6 6 , 7}$ \\
\hline $\mathbf{4}$ & Las Condes & 48,5 & 61,9 & 63,6 & 69,8 & 79,3 & 50,1 & $\mathbf{6 1 , 6}$ \\
\hline $\mathbf{5}$ & Santiago & 60,4 & 74,0 & 41,1 & 14,5 & 48,0 & 66,7 & $\mathbf{5 4 , 7}$ \\
\hline $\mathbf{6}$ & La Reina & 46,9 & 20,4 & 49,3 & 67,9 & 84,2 & 46,9 & $\mathbf{5 1 , 9}$ \\
\hline $\mathbf{7}$ & Nuñoa & 51,0 & 27,0 & 38,5 & 42,7 & 66,2 & 45,7 & $\mathbf{4 5 , 5}$ \\
\hline $\mathbf{8}$ & San Pedro de la Paz & 43,3 & 18,0 & 56,0 & 56,1 & 64,3 & 35,7 & $\mathbf{4 4 , 3}$ \\
\hline $\mathbf{9}$ & Macul & 51,6 & 14,2 & 48,6 & 56,6 & 60,9 & 39,7 & $\mathbf{4 3 , 7}$ \\
\hline $\mathbf{1 0}$ & Valdivia & 41,9 & 15,3 & 50,1 & 52,5 & 42,1 & 49,9 & $\mathbf{4 2 , 4}$ \\
\hline $\mathbf{1 1}$ & Concón & 44,1 & 16,3 & 53,4 & 47,1 & 67,2 & 31,6 & $\mathbf{4 2 , 2}$ \\
\hline $\mathbf{1 2}$ & Osorno & 45,7 & 15,9 & 53,0 & 48,3 & 39,9 & 44,8 & $\mathbf{4 1 , 1}$ \\
\hline $\mathbf{1 3}$ & Cerrillos & 32,2 & 24,9 & 39,6 & 32,3 & 53,9 & 45,6 & $\mathbf{4 0 , 3}$ \\
\hline $\mathbf{1 4}$ & La Serena & 63,0 & 19,5 & 51,3 & 41,2 & 46,6 & 29,8 & $\mathbf{3 9 , 2}$ \\
\hline $\mathbf{1 5}$ & Puerto Varas & 37,1 & 17,2 & 55,2 & 42,3 & 67,4 & 22,5 & $\mathbf{3 8 , 9}$ \\
\hline $\mathbf{1 6}$ & San Miguel & 39,4 & 25,1 & 35,6 & 23,6 & 59,7 & 37,8 & $\mathbf{3 8 , 3}$ \\
\hline $\mathbf{1 7}$ & Huechuraba & 37,6 & 27,1 & 24,4 & 47,5 & 58,0 & 33,7 & $\mathbf{3 7 , 2}$ \\
\hline $\mathbf{1 8}$ & Viña del Mar & 49,8 & 22,2 & 46,6 & 47,0 & 25,2 & 39,4 & $\mathbf{3 6 , 9}$ \\
\hline $\mathbf{1 9}$ & Punta Arenas & 34,1 & 19,2 & 51,5 & 51,7 & 41,2 & 29,7 & $\mathbf{3 6 , 4}$ \\
\hline $\mathbf{2 0}$ & Machalí & 44,8 & 14,1 & 47,9 & 49,1 & 63,8 & 16,7 & $\mathbf{3 6 , 1}$ \\
\hline $\mathbf{2 1}$ & Chillán Viejo & 43,3 & 17,5 & 44,2 & 22,7 & 65,7 & 23,6 & $\mathbf{3 5 , 9}$ \\
\hline $\mathbf{2 2}$ & Concepción & 43,1 & 23,2 & 49,5 & 32,3 & 36,6 & 32,1 & $\mathbf{3 5 , 6}$ \\
\hline $\mathbf{2 3}$ & Iquique & 42,8 & 22,1 & 45,9 & 34,6 & 37,9 & 33,2 & $\mathbf{3 5 , 5}$ \\
\hline $\mathbf{2 4}$ & Coyhaique & 38,6 & 17,1 & 55,7 & 29,2 & 56,7 & 17,9 & $\mathbf{3 4 , 6}$ \\
\hline & PROMEDI0 & $\mathbf{3 9 , 4}$ & $\mathbf{1 7 , 4}$ & $\mathbf{3 9 , 5}$ & $\mathbf{4 5 , 5}$ & $\mathbf{4 6 , 6}$ & $\mathbf{2 8 , 1}$ & $\mathbf{3 4 , 5}$ \\
\hline
\end{tabular}

Fuente: elaboración propia, 2012. 
TABLE 4: MUNICIPALITIES WITH A 2002 UQLI SCORE ABOVE THE NATIONAL AVERAGE.

\begin{tabular}{|c|c|c|c|c|c|c|c|c|}
\hline PLACE & MUNICIPALITY & WS & $\mathrm{BE}$ & SC & $\mathrm{CM}$ & $\mathrm{HE}$ & HLE & UOLI \\
\hline 1 & Vitacura & 59.0 & 55.7 & 59.3 & 78.0 & 9.5 & 86.5 & 75.4 \\
\hline 2 & Lo Barnechea & 35.0 & 52.3 & 46.9 & 85.4 & 86.5 & 79.5 & 67.2 \\
\hline 3 & Providencia & 64.5 & 55.0 & 49.3 & 74.9 & 80.9 & 72.3 & 66.7 \\
\hline 4 & Las Condes & 48.5 & 61.9 & 63.6 & 69.8 & 79.3 & 50.1 & 61.6 \\
\hline 5 & Santiago & 60.4 & 74.0 & 41.1 & 14.5 & 48.0 & 66.7 & 54.7 \\
\hline 6 & La Reina & 46.9 & 20.4 & 49.3 & 67.9 & 84.2 & 46.9 & 51.9 \\
\hline 7 & Ñuñoa & 51.0 & 27.0 & 38.5 & 42.7 & 66.2 & 45.7 & 45.5 \\
\hline 8 & San Pedro de la Paz & 43.3 & 18.0 & 56.0 & 56.1 & 64.3 & 35.7 & 44.3 \\
\hline 9 & Macul & 51.6 & 14.2 & 48.6 & 56.6 & 60.9 & 39.7 & 43.7 \\
\hline 10 & Valdivia & 41.9 & 15.3 & 50.1 & 52.5 & 42.1 & 49.9 & 42.4 \\
\hline 11 & Concón & 44.1 & 16.3 & 53.4 & 47.1 & 67.2 & 31.6 & 42.2 \\
\hline 12 & Osorno & 45.7 & 15.9 & 53.0 & 48.3 & 39.9 & 44.8 & 41.1 \\
\hline 13 & Cerrillos & 32.2 & 24.9 & 39.6 & 32.3 & 53.9 & 45.6 & 40.3 \\
\hline 14 & La Serena & 63.0 & 19.5 & 51.3 & 41.2 & 46.6 & 29.8 & 39.2 \\
\hline 15 & Puerto Varas & 37.1 & 17.2 & 55.2 & 42.3 & 67.4 & 22.5 & 38.9 \\
\hline 16 & San Miguel & 39.4 & 25.1 & 35.6 & 23.6 & 59.7 & 37.8 & 38.3 \\
\hline 17 & Huechuraba & 37.6 & 27.1 & 24.4 & 47.5 & 58.0 & 33.7 & 37.2 \\
\hline 18 & Viña del Mar & 49.8 & 22.2 & 46.6 & 47.0 & 25.2 & 39.4 & 36.9 \\
\hline 19 & Punta Arenas & 34.1 & 19.2 & 51.5 & 51.7 & 41.2 & 29.7 & 36.4 \\
\hline 20 & Machalí & 44.8 & 14.1 & 47.9 & 49.1 & 63.8 & 16.7 & 36.1 \\
\hline 21 & Chillan Viejo & 43.3 & 17.5 & 44.2 & 22.7 & 65.7 & 23.6 & 35.9 \\
\hline 22 & Concepción & 43.1 & 23.2 & 49.5 & 32.3 & 36.6 & 32.1 & 35.6 \\
\hline 23 & Iquique & 42.8 & 22.1 & 45.9 & 34.6 & 37.9 & 33.2 & 35.5 \\
\hline \multirow[t]{2}{*}{24} & Coyhaique & 38.6 & 17.1 & 55.7 & 29.2 & 56.7 & 17.9 & 34.6 \\
\hline & AVERAGE & 39.4 & 17.4 & 39.5 & 45.5 & 46.6 & 28.1 & 34.5 \\
\hline
\end{tabular}

Source: prepared by authors, 2012 
TABLA 5: COMUNAS CON ICVU 2002 MENOR AL PROMEDIO NACIONAL.

\begin{tabular}{|c|c|c|c|c|c|c|c|c|}
\hline POSICIÓN & COMUNA & $C L$ & AN & CS & $\mathrm{CM}$ & SM & VE & ICVU \\
\hline 25 & Quilicura & 44,3 & 28,6 & 32,9 & 54,1 & 50,4 & 15,6 & 33,5 \\
\hline 26 & La Florida & 40,5 & 21,2 & 41,7 & 53,6 & 28,7 & 29,6 & 33,4 \\
\hline 27 & Quilpué & 39,8 & 16,5 & 50,8 & 45,2 & 42,9 & 20,6 & 33,4 \\
\hline 28 & Coquimbo & 48,2 & 13,7 & 41,6 & 45,5 & 38,4 & 27,8 & 33,4 \\
\hline 29 & Temuco & 48,9 & 21,2 & 39,8 & 49,5 & 32,6 & 26,6 & 33,3 \\
\hline 30 & La Cisterna & 44,1 & 8,9 & 29,7 & 27,5 & 59,6 & 28,7 & 32,8 \\
\hline 31 & Villa Alemana & 42,5 & 3,4 & 52,4 & 44,8 & 49,5 & 19,5 & 32,7 \\
\hline 32 & Copiapó & 38,0 & 13,2 & 49,5 & 47,6 & 42,7 & 19,3 & 32,3 \\
\hline 33 & Antofagasta & 45,4 & 27,2 & 45,9 & 46,3 & 21,5 & 23,7 & 31,9 \\
\hline 34 & Independencia & 24,6 & 11,1 & 27,3 & 31,8 & 52,9 & 34,8 & 31,8 \\
\hline 35 & Maipú & 40,2 & 27,0 & 36,8 & 49,3 & 22,9 & 28,3 & 31,6 \\
\hline 36 & San Antonio & 41,6 & 9,1 & 42,8 & 40,5 & 43,4 & 22,5 & 31,2 \\
\hline 37 & Estación Central & 38,9 & 8,7 & 34,7 & 28,1 & 44,4 & 28,6 & 30,3 \\
\hline 38 & Talca & 48,4 & 18,3 & 35,3 & 40,4 & 30,2 & 24,6 & 30,2 \\
\hline 39 & Chiguayante & 34,8 & 7,0 & 27,5 & 54,3 & 59,5 & 16,7 & 30,1 \\
\hline 40 & Rancagua & 36,0 & 22,9 & 37,6 & 48,6 & 38,0 & 15,6 & 29,8 \\
\hline 41 & Peñalolén & 38,7 & 15,3 & 29,6 & 55,5 & 40,9 & 19,8 & 29,8 \\
\hline 42 & San Joaquín & 27,8 & 10,0 & 25,3 & 45,8 & 49,9 & 26,1 & 29,7 \\
\hline 43 & Padre las Casas & 32,5 & 8,2 & 38,6 & 48,4 & 47,7 & 17,8 & 29,6 \\
\hline 44 & Talcahuano & 44,8 & 10,7 & 40,8 & 42,9 & 25,2 & 26,8 & 29,5 \\
\hline 45 & Arica & 53,6 & 15,9 & 34,4 & 37,7 & 32,9 & 21,5 & 29,5 \\
\hline 46 & Puerto Montt & 31,0 & 23,3 & 38,4 & 42,0 & 31,8 & 21,6 & 29,5 \\
\hline 47 & Chillán & 40,7 & 13,2 & 44,8 & 44,7 & 33,4 & 17,8 & 29,3 \\
\hline 48 & Renca & 27,3 & 6,6 & 45,9 & 42,8 & 44,8 & 15,7 & 28,5 \\
\hline 49 & Coronel & 20,9 & 7,3 & 50,9 & 47,6 & 38,9 & 15,8 & 28,2 \\
\hline 50 & San Ramón & 26,3 & 5,1 & 36,5 & 52,6 & 43,7 & 18,4 & 28,0 \\
\hline 51 & Puente Alto & 49,8 & 23,5 & 32,6 & 49,5 & 20,6 & 17,6 & 27,7 \\
\hline 52 & Recoleta & 32,1 & 11,1 & 35,2 & 45,9 & 36,1 & 18,9 & 27,4 \\
\hline 53 & Pedro Aguirre Cerda & 24,7 & 7,3 & 33,0 & 45,4 & 42,5 & 19,0 & 26,9 \\
\hline
\end{tabular}




\begin{tabular}{lllllllll}
\hline POSICIÓN & COMUNA & CL & AN & CS & CM & SM & VE & ICVU \\
\hline $\mathbf{5 4}$ & Tomé & 15,4 & 2,1 & 28,9 & 42,7 & 48,2 & 24,2 & $\mathbf{2 6 , 8}$ \\
\hline $\mathbf{5 5}$ & Quinta Normal & 23,0 & 12,4 & 30,2 & 24,4 & 45,4 & 22,0 & $\mathbf{2 6 , 6}$ \\
\hline $\mathbf{5 6}$ & Conchalí & 29,6 & 6,2 & 24,2 & 48,4 & 42,0 & 20,3 & $\mathbf{2 6 , 2}$ \\
\hline $\mathbf{5 7}$ & Pudahuel & 32,9 & 6,2 & 24,6 & 49,7 & 38,0 & 20,8 & $\mathbf{2 6 , 1}$ \\
\hline $\mathbf{5 8}$ & Lo Prado & 24,6 & 5,4 & 26,6 & 40,1 & 48,1 & 18,1 & $\mathbf{2 5 , 7}$ \\
\hline $\mathbf{5 9}$ & Penco & 41,7 & 3,1 & 26,4 & 40,0 & 51,2 & 11,6 & $\mathbf{2 5 , 6}$ \\
\hline $\mathbf{6 0}$ & La Granja & 36,3 & 2,0 & 35,5 & 48,6 & 40,8 & 11,9 & $\mathbf{2 5 , 4}$ \\
\hline $\mathbf{6 1}$ & Valparaíso & 36,5 & 14,9 & 41,5 & 38,8 & 18,6 & 17,2 & $\mathbf{2 5 , 1}$ \\
\hline $\mathbf{6 2}$ & La Pintana & 47,1 & 2,6 & 27,7 & 48,0 & 31,3 & 16,4 & $\mathbf{2 4 , 6}$ \\
\hline $\mathbf{6 3}$ & Lota & 21,9 & 2,3 & 30,5 & 45,2 & 43,1 & 13,9 & $\mathbf{2 4 , 0}$ \\
\hline $\mathbf{6 4}$ & El Bosque & 29,9 & 3,7 & 29,9 & 43,4 & 37,9 & 14,0 & $\mathbf{2 3 , 7}$ \\
\hline $\mathbf{6 5}$ & San Bernardo & 34,9 & 10,2 & 27,6 & 37,1 & 26,8 & 10,5 & $\mathbf{2 1 , 2}$ \\
\hline $\mathbf{6 6}$ & Cerro Navia & $\mathbf{2 9 , 7}$ & 1,9 & $\mathbf{7 , 8}$ & 47,0 & 33,9 & $\mathbf{2 0 , 9}$ & $\mathbf{2 1 , 1}$ \\
\hline $\mathbf{6 7}$ & Lo Espejo & 31,0 & 2,6 & 13,2 & 36,8 & 40,9 & 13,9 & $\mathbf{2 0 , 7}$ \\
\hline & PROMEDI0 & $\mathbf{3 9 , 4}$ & $\mathbf{1 7 , 4}$ & $\mathbf{3 9 , 5}$ & $\mathbf{4 5 , 5}$ & $\mathbf{4 6 , 6}$ & $\mathbf{2 8 , 1}$ & $\mathbf{3 4 , 5}$ \\
\hline
\end{tabular}

Fuente: elaboración propia, 2012

TABLE 5: MUNICIPALITIES WITH A 2002 UQLI SCORE BELOW THE NATIONAL AVERAGE.

\begin{tabular}{lllllllll}
\hline PLACE & MUNICIPALITY & WS & BE & SC & CM & HE & HLE & UQLI \\
\hline $\mathbf{2 5}$ & Quilicura & 44.3 & 28.6 & 32.9 & 54.1 & 50.4 & 15.6 & $\mathbf{3 3 . 5}$ \\
\hline $\mathbf{2 6}$ & La Florida & 40.5 & 21.2 & 41.7 & 53.6 & 28.7 & 29.6 & $\mathbf{3 3 . 4}$ \\
\hline $\mathbf{2 7}$ & Quilpué & 39.8 & 16.5 & 50.8 & 45.2 & 42.9 & 20.6 & $\mathbf{3 3 . 4}$ \\
\hline $\mathbf{2 8}$ & Coquimbo & 48.2 & 13.7 & 41.6 & 45.5 & 38.4 & 27.8 & $\mathbf{3 3 . 4}$ \\
\hline $\mathbf{2 9}$ & Temuco & 48.9 & 21.2 & 39.8 & 49.5 & 32.6 & 26.6 & $\mathbf{3 3 . 3}$ \\
\hline $\mathbf{3 0}$ & La Cisterna & 44.1 & 8.9 & 29.7 & 27.5 & 59.6 & 28.7 & $\mathbf{3 2 . 8}$ \\
\hline $\mathbf{3 1}$ & Villa Alemana & 42.5 & 3.4 & 52.4 & 44.8 & 49.5 & 19.5 & $\mathbf{3 2 . 7}$ \\
\hline $\mathbf{3 2}$ & Copiapó & 38.0 & 13.2 & 49.5 & 47.6 & 42.7 & 19.3 & $\mathbf{3 2 . 3}$ \\
\hline $\mathbf{3 3}$ & Antofagasta & 45.4 & 27.2 & 45.9 & 46.3 & 21.5 & 23.7 & $\mathbf{3 1 . 9}$ \\
\hline $\mathbf{3 4}$ & Independencia & 24.6 & 11.1 & 27.3 & 31.8 & 52.9 & 34.8 & $\mathbf{3 1 . 8}$ \\
\hline $\mathbf{3 5}$ & Maipú & 40.2 & 27.0 & 36.8 & 49.3 & 22.9 & 28.3 & $\mathbf{3 1 . 6}$ \\
\hline $\mathbf{3 6}$ & San Antonio & 41.6 & 9.1 & 42.8 & 40.5 & 43.4 & 22.5 & $\mathbf{3 1 . 2}$ \\
\hline
\end{tabular}




\begin{tabular}{|c|c|c|c|c|c|c|c|c|}
\hline PLACE & MUNICIPALITY & WS & $\mathrm{BE}$ & SC & $\mathrm{CM}$ & HE & HLE & UQLI \\
\hline 37 & Estación Central & 38.9 & 8.7 & 34.7 & 28.1 & 44.4 & 28.6 & 30.3 \\
\hline 38 & Talca & 48.4 & 18.3 & 35.3 & 40.4 & 30.2 & 24.6 & 30.2 \\
\hline 39 & Chiguayante & 34.8 & 7.0 & 27.5 & 54.3 & 59.5 & 16.7 & 30.1 \\
\hline 40 & Rancagua & 36.0 & 22.9 & 37.6 & 48.6 & 38.0 & 15.6 & 29.8 \\
\hline 41 & Peñalolén & 38.7 & 15.3 & 29.6 & 55.5 & 40.9 & 19.8 & 29.8 \\
\hline 42 & San Joaquín & 27.8 & 10.0 & 25.3 & 45.8 & 49.9 & 26.1 & 29.7 \\
\hline 43 & Padre las Casas & 32.5 & 8.2 & 38.6 & 48.4 & 47.7 & 17.8 & 29.6 \\
\hline 44 & Talcahuano & 44.8 & 10.7 & 40.8 & 42.9 & 25.2 & 26.8 & 29.5 \\
\hline 45 & Arica & 53.6 & 15.9 & 34.4 & 37.7 & 32.9 & 21.5 & 29.5 \\
\hline 46 & Puerto Montt & 31.0 & 23.3 & 38.4 & 42.0 & 31.8 & 21.6 & 29.5 \\
\hline 47 & Chillan & 40.7 & 13.2 & 44.8 & 44.7 & 33.4 & 17.8 & 29.3 \\
\hline 48 & Renca & 27.3 & 6.6 & 45.9 & 42.8 & 44.8 & 15.7 & 28.5 \\
\hline 49 & Coronel & 20.9 & 7.3 & 50.9 & 47.6 & 38.9 & 15.8 & 28.2 \\
\hline 50 & San Ramón & 26.3 & 5.1 & 36.5 & 52.6 & 43.7 & 18.4 & 28.0 \\
\hline 51 & Puente Alto & 49.8 & 23.5 & 32.6 & 49.5 & 20.6 & 17.6 & 27.7 \\
\hline 52 & Recoleta & 32.1 & 11.1 & 35.2 & 45.9 & 36.1 & 18.9 & 27.4 \\
\hline 53 & Pedro Aguirre Cerda & 24.7 & 7.3 & 33.0 & 45.4 & 42.5 & 19.0 & 26.9 \\
\hline 54 & Tomé & 15.4 & 2.1 & 28.9 & 42.7 & 48.2 & 24.2 & 26.8 \\
\hline 55 & Quinta Normal & 23.0 & 12.4 & 30.2 & 24.4 & 45.4 & 22.0 & 26.6 \\
\hline 56 & Conchalí & 29.6 & 6.2 & 24.2 & 48.4 & 42.0 & 20.3 & 26.2 \\
\hline 57 & Pudahuel & 32.9 & 6.2 & 24.6 & 49.7 & 38.0 & 20.8 & 26.1 \\
\hline 58 & Lo Prado & 24.6 & 5.4 & 26.6 & 40.1 & 48.1 & 18.1 & 25.7 \\
\hline 59 & Penco & 41.7 & 3.1 & 26.4 & 40.0 & 51.2 & 11.6 & 25.6 \\
\hline 60 & La Granja & 36.3 & 2.0 & 35.5 & 48.6 & 40.8 & 11.9 & 25.4 \\
\hline 61 & Valparaíso & 36.5 & 14.9 & 41.5 & 38.8 & 18.6 & 17.2 & 25.1 \\
\hline 62 & La Pintana & 47.1 & 2.6 & 27.7 & 48.0 & 31.3 & 16.4 & 24.6 \\
\hline 63 & Lota & 21.9 & 2.3 & 30.5 & 45.2 & 43.1 & 13.9 & 24.0 \\
\hline 64 & El Bosque & 29.9 & 3.7 & 29.9 & 43.4 & 37.9 & 14.0 & 23.7 \\
\hline 65 & San Bernardo & 34.9 & 10.2 & 27.6 & 37.1 & 26.8 & 10.5 & 21.2 \\
\hline 66 & Cerro Navia & 29.7 & 1.9 & 7.8 & 47.0 & 33.9 & 20.9 & 21.1 \\
\hline \multirow[t]{2}{*}{67} & Lo Espejo & 31.0 & 2.6 & 13.2 & 36.8 & 40.9 & 13.9 & 20.7 \\
\hline & AVERAGE & 39.4 & 17.4 & 39.5 & 45.5 & 46.6 & 28.1 & 34.5 \\
\hline
\end{tabular}

Source: prepared by authors, 2012 
67 comunas urbanas consignadas en este estudio ofrecían una calidad de vida superior al promedio nacional el año 2002, 11 del Gran Santiago y 13 de regiones, incluyendo solo a 6 capitales regionales, en orden: Santiago (5), Valdivia (10), Punta Arenas (19), Concepción (22), Iquique (23) y Coyhaique (24).

Por otra parte, al observar la Tabla 5, donde se presenta el ranking de aquellas comunas que obtuvieron un ICVU inferior al promedio nacional el año 2002, se puede constatar que de las diez comunas con menor ICVU, siete eran del Gran Santiago, de menor a mayor: Lo Espejo, Cerro Navia, San Bernardo, El Bosque, La Pintana, La Granja (60) y Lo Prado (58). Completan el grupo de las diez comunas con menor ICVU 2002, las comunas de la Región del Biobío: Lota (63) y Penco (59) y Valparaíso (61). Adicionalmente, resulta significativo el hecho de que la mayoría de las capitales regionales importantes alcancen un ICVU por debajo de la media nacional, especialmente en el caso de Valparaíso, cuyo índice $(25,1)$ lo pone más cerca del fondo del ranking que de la media nacional.

En relación a los resultados obtenidos en las tres principales áreas metropolitanas de Chile, Gran Santiago, Gran Valparaíso y Gran Concepción, el ICVU 2002 evidencia que el desequilibrio era mayor al interior de las mismas áreas metropolitanas que al comparar la situación de calidad de
Therefore, it can be stated that 24 out of the 67 urban municipalities included in this research offered a quality of life that exceeded the national average back in 2002, from this figure, 11 municipalities belong to Greater Santiago and 13 to the rest of the regions, including only 6 regional capitals: Santiago (5), Valdivia (10), Punta Arenas (19), Concepción (22), Iquique (23) and Coyhaique (24).

Furthermore, table 5 shows that seven out of the top ten municipalities with a 2002 UQLI score below the national average belong to Greater Santiago, sorted from lower to higher, they are: Lo Espejo, Cerro Navia, San Bernardo, El Bosque, La Pintana, La Granja (ranked 60th) and Lo Prado (ranked 58th.) This list of the ten municipalities with 2002 UQLI scores below the national average is completed by two municipalities belonging to the Biobio Region: Lota (ranked 63rd) and Penco (ranked 59th); and Valparaíso (ranked 61st.) In addition, it is worth pointing out that a significant number of the most important regional capitals achieved UQLI scores below the national average, especially Valparaiso, whose score (25.1) ranks at the bottom of this list, away from the national average.

In relation to the results obtained in the three main Chilean metropolitan areas: Greater Santiago, Greater Valparaíso and Greater Concepción, the 
vida urbana considerando todas las comunas del estudio. Por ende, para el caso del Gran Santiago se observa en la figura 4 que solo 11 de las 34 comunas superaban la media nacional, es decir, equivalente a un $24,5 \%$ de la población, lo que significa que de cada cuatro habitantes tres vivían en comunas que mostraban un ICVU inferior a la media nacional. Junto con lo anterior, cabe destacar que siendo la media del Gran Santiago $(35,7)$ superior a la media nacional $(34,5)$ para el año 2002, implica que la situación en el área metropolitana evidenciaba un alto grado de inequidad entre sus comunas.

En el caso del Gran Valparaíso la situación se representa en la figura 5, donde se muestra que en el año 2002 la calidad de vida urbana era superior a la media nacional en las comunas de Concón y Viña del Mar, mientras que Quilpué, Villa Alemana y Valparaíso mostraban una situación de rezago, ya que sostenían un ICVU inferior a la media nacional, siendo particularmente preocupante el caso de Valparaíso en su condición de capital regional. Esto significa que en esta área metropolitana un $61 \%$ de la población tenía una calidad de vida inferior a la media nacional, mientras que la media del Gran Valparaíso $(34,1)$ se mostraba levemente inferior a la media nacional $(34,5)$.

Por último, para el caso del Gran Concepción se pueden observar los resultados en la figura 6 , que muestra a las comunas San Pedro de la Paz
2002 UQLI shows that inequality was greater within metropolitan areas than comparing the urban quality of life situation among all of the analyzed municipalities. Thus, graphic 4 shows that only 11 out of the 34 municipalities of Greater Santiago exceeded the national average, that is to say, $24.5 \%$ of the population; this means that three out of four people lived in municipalities with UQLI scores below the national average. In addition, it is worth pointing out that there were greater levels of inequity among municipalities within the metropolitan region in 2002 as the result of the average of Greater Santiago (35.7) being higher than the national average (34.5.)

In the case of Greater Valparaiso, Graphic 5 shows that, while Concón and Viña del Mar had a quality of life that exceeded the national average back in 2002, Quilpué, Villa Alemana and Valparaiso had UQLI scores below the national average; in this line, Valparaiso revealed an alarming situation due to its condition of regional capital. This means that $61 \%$ of the population of this metropolitan area experienced a quality of life below the national average, whereas the average of Greater Valparaíso (34.1) was slightly below the national average (34.5).

Lastly, in the case of Greater Concepcion, Graphic 6 shows that San Pedro de la Paz and Concepción 
FIGURA 4: RANKING DE COMUNAS DEL GRAN SANTIAGO SEGÚN ICVU 2002. GRAPHIC 4: RANKED LIST OF MUNICIPALITIES BELONGING TO GREATER SANTIAGO ACCORDING TO THE 2002 UQLI

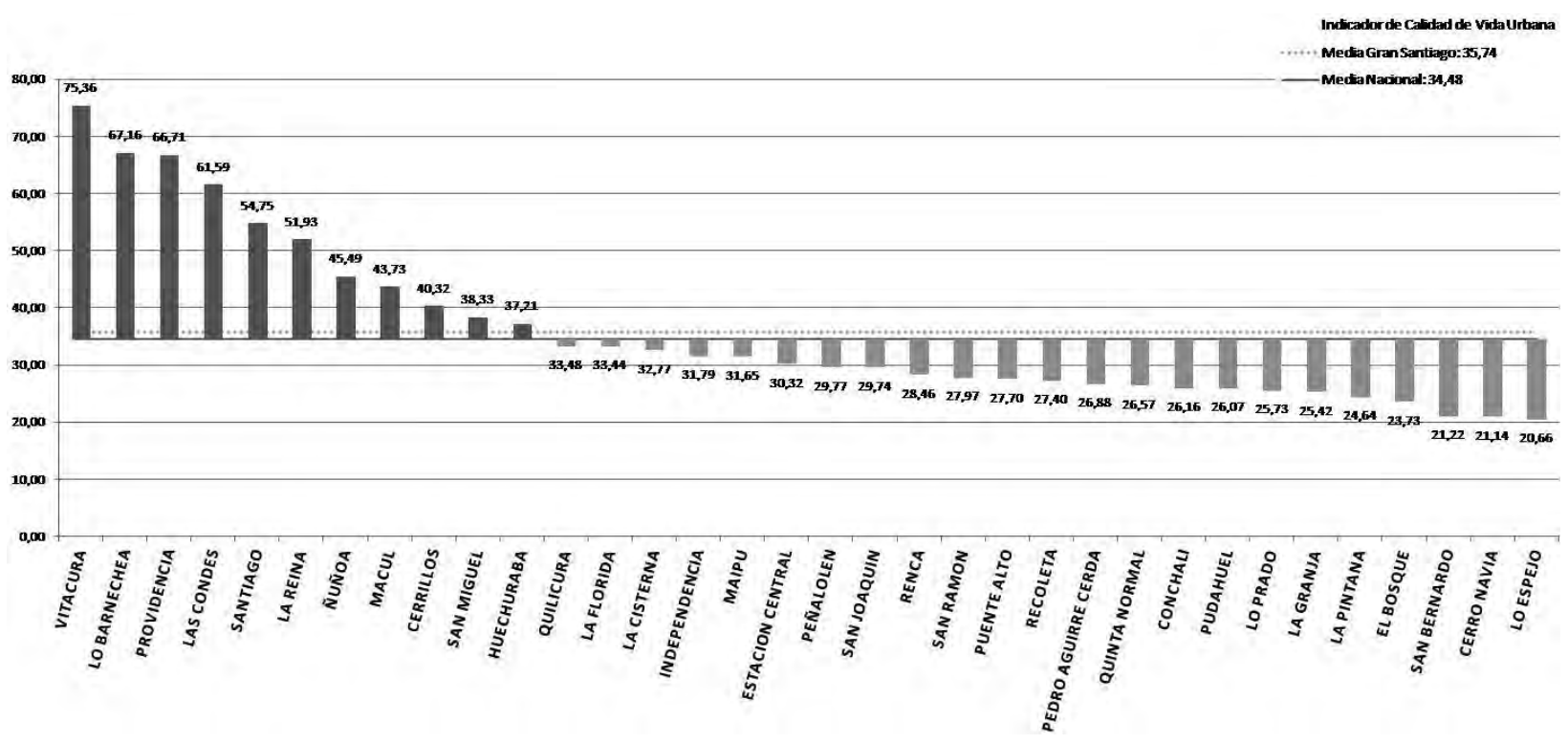

Fuente: elaboración propia, 2012. Source: prepared by authors, 2012

y Concepción con un ICVU superior a la media nacional, y el resto de las comunas con valores significativamente menores, con Lota ocupando el último lugar. En términos de población, esto significa que el 36,2\% de la población tenía una calidad de vida superior a la media nacional. Se reporta además que la media del Gran Concepción $(30,5)$ era inferior a la media nacional $(34,5)$. present UQLI scores above the national average; the rest of the municipalities show significantly lower values, with Lota holding the last place in the list. In population terms, $36.2 \%$ of the population experienced a quality of life above the national average. It is also reported that the average of Greater Concepción (30.5) was lower than the national average (34.5). 
FIGURA 5: RANKING DE COMUNAS DEL GRAN VALPARAÍSO SEGÚN ICVU 2002.

GRAPHIC 5: RANKED LIST OF MUNICIPALITIES BELONGING TO GREATER VALPARAÍSO ACCORDING TO THE 2002 UQLI

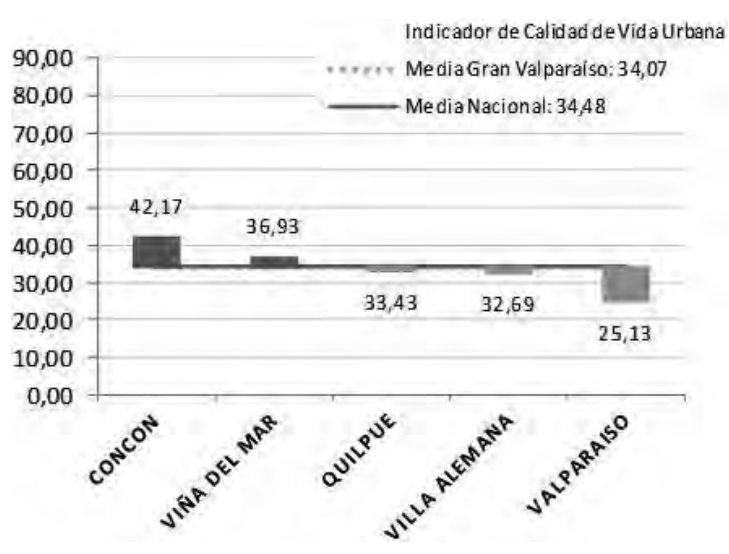

Fuente: elaboración propia, 2012. Source: prepared by authors, 2012.

\section{Análisis de tendencia 2002- 2012}

Para efectuar un análisis de los cambios producidos en la calidad de vida urbana entre comunas en el período 2002-2012, se pueden hacer comparaciones de la posición relativa que ocupaba cada comuna en los años de análisis de acuerdo al ranking correspondiente. Se prefiere este método

\section{FIGURA 6: RANKING DE COMUNAS DEL GRAN CONCEPCIÓN SEGÚN ICVU 2002. \\ GRAPHIC 6: RANKED LIST OF MUNICIPALITIES BELONGING TO GREATER CONCEPCIÓN ACCORDING TO THE 2002 UQLI}

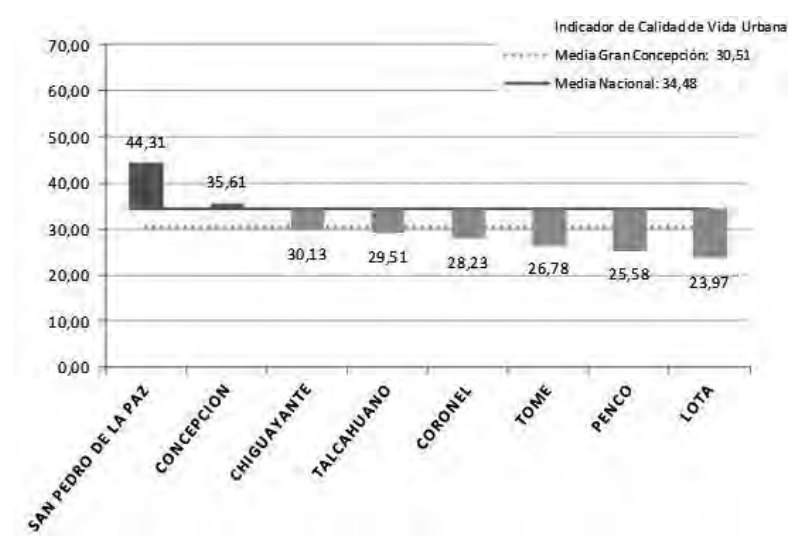

Fuente: elaboración propia, 2012.

Source: prepared by authors, 2012.

\section{2-2012 Trend Analysis}

Based on the corresponding ranked list, different comparisons on the relative position of each municipality can be conducted in order to analyze the changes in the urban quality of life among municipalities over the 2002-2012 period. Such a method of analysis is preferred due to the inconsistency of comparing yearly indicators, 
de análisis porque no resulta lógico comparar el índice propiamente tal de un año con otro, ya que la metodología empleada para construir el ICVU modifica levemente las variables usadas cada año y lo importante es la posición relativa de cada comuna en el ranking global.

Para hacer un análisis comparado de los cambios en la calidad de vida urbana en las tres áreas metropolitanas principales, Gran Santiago, Gran Valparaíso y Gran Concepción, se pueden usar las ventajas visuales de los sistemas de información geográfica para examinar los patrones de distribución de los ICVU en los años 2002 y 2012. Bajo el criterio de corte natural se fijaron los rangos para determinar niveles de calidad de vida urbana: Alto, Medio, Bajo y Muy Bajo. Es así como comparando la figura 7 y la figura 8 , se pueden ver los cambios experimentados en una década en materia de calidad de vida urbana en las comunas del Gran Santiago.

De acuerdo a la visualización de la cartografía para cada año, se puede afirmar que hay una disminución de la brecha en la calidad de vida urbana entre 2002 y 2012 en el Gran Santiago, particularmente, porque son más las comunas que mejoran su ICVU que aquellas que lo empeoran. Especialmente las comunas del norponiente y suroriente son las que ven mejorada su situación. since the methodology to develop the UQLI slightly modifies the variables used every year; in this case, what is important is the relative position of each municipality in the global ranked list.

Visual advantages provided by geographical information systems designed to analyze the distribution patterns of the UQLI for 2002 and 2012 can be used to conduct a comparative analysis on the changes in the urban quality of life within the three main metropolitan areas: Greater Santiago, Greater Valparaiso and Greater Concepción. The natural cut-off criteria was used to determine the different urban quality of life levels: High, Medium, Low and Very Low. Thus, the comparison of graphic 7 and graphic 8 shows the changes in the urban quality of life within the municipalities belonging to Greater Santiago over a decade.

According to the visualization of the mapping results for each year, it can be stated that there has been a significant narrowing in the urban quality of life gap over the 2002-2012 period in Greater Santiago; the reason is that the number of municipalities that increased their UQLI scores was higher than the number of those municipalities that lower their indicators. In this context, those municipalities located in the north-west and southeast areas of the city improved their situation. 
FIGURA 7: INDICADOR DE CALIDAD DE VIDA URBANA (ICVU). GRAN SANTIAGO, RESULTADOS 2002 GRAPHIC 7: 2002 RESULTS OF URBAN QUALITY OF LIFE INDEX (UOLI) FOR GREATER SANTIAGO

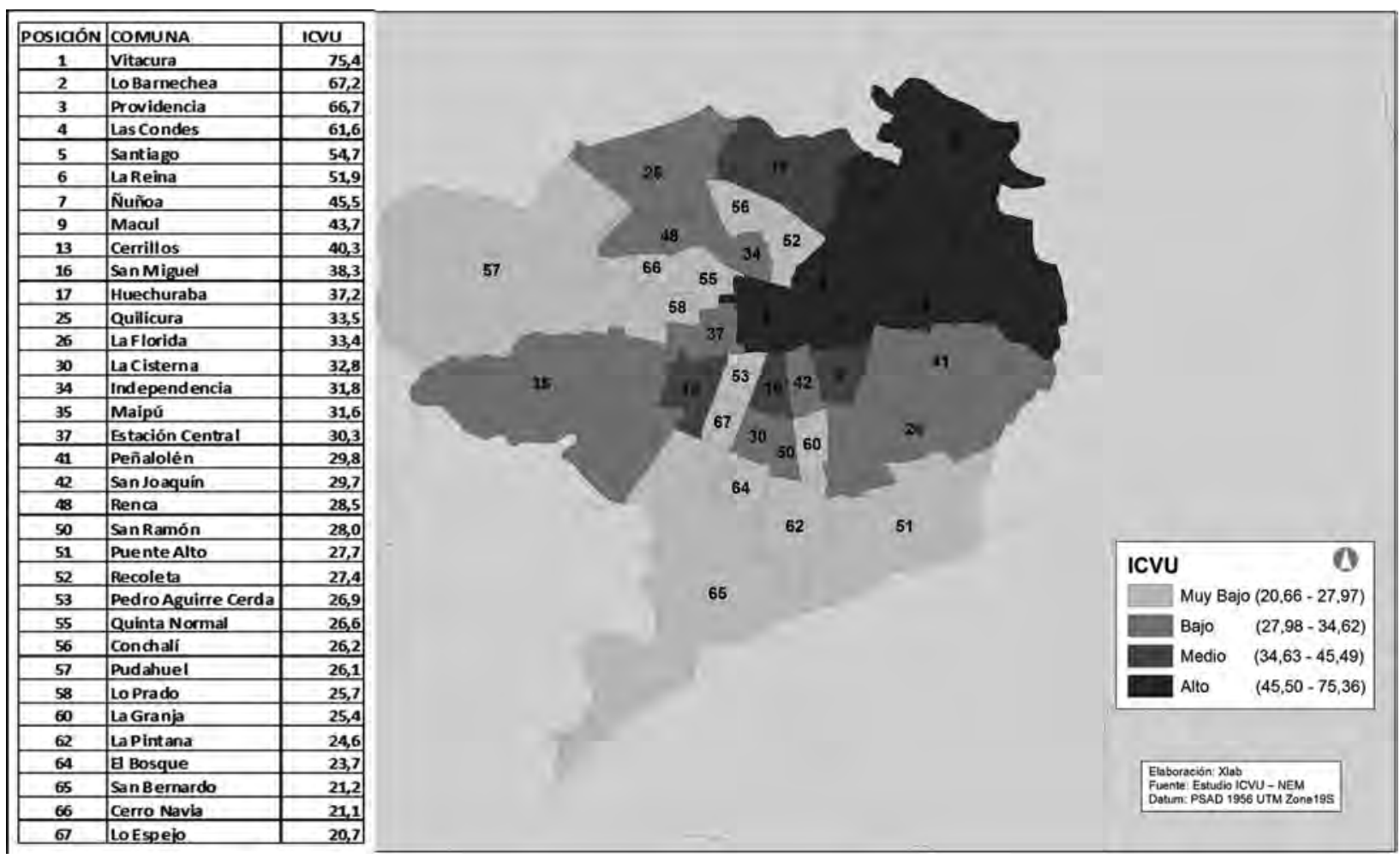

Fuente: elaboración propia, 2012.

Source: prepared by authors, 2012 
FIGURA 8: INDICADOR DE CALIDAD DE VIDA URBANA (ICVU). GRAN SANTIAGO, RESULTADOS 2012 GRAPHIC 8: 2012 RESULTS OF URBAN QUALITY OF LIFE INDEX (UQLI) FOR GREATER SANTIAGO

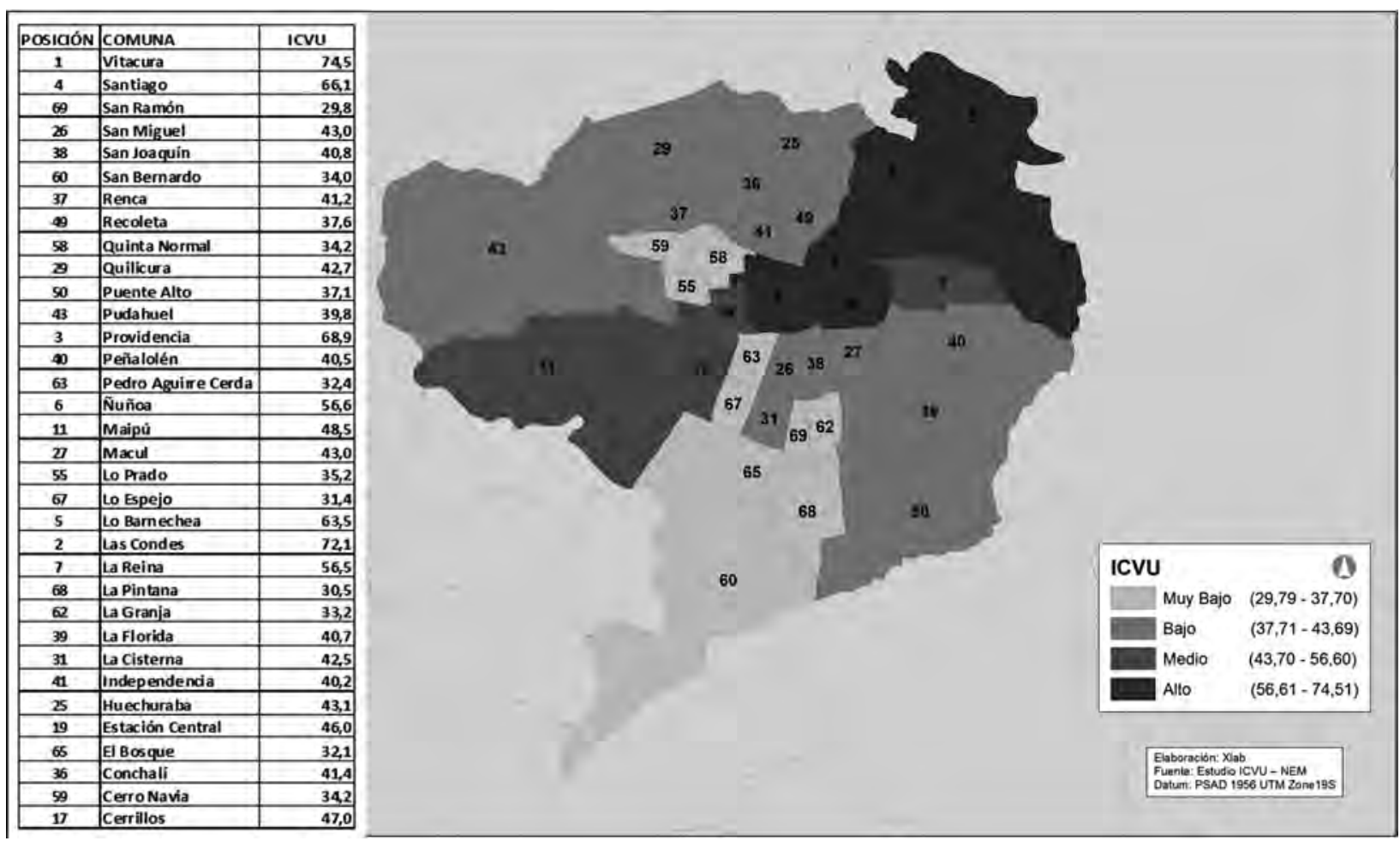

Fuente: elaboración propia, 2012.

Source: prepared by authors, 2012 
FIGURA 9: INDICADOR DE CALIDAD DE VIDA URBANA (ICVU). GRAN VALPARAÍSO, RESULTADOS 2002 GRAPHIC 9: 2002 RESULTS OF URBAN QUALITY OF LIFE INDEX (UQLI) FOR GREATER VALPARAÍSO

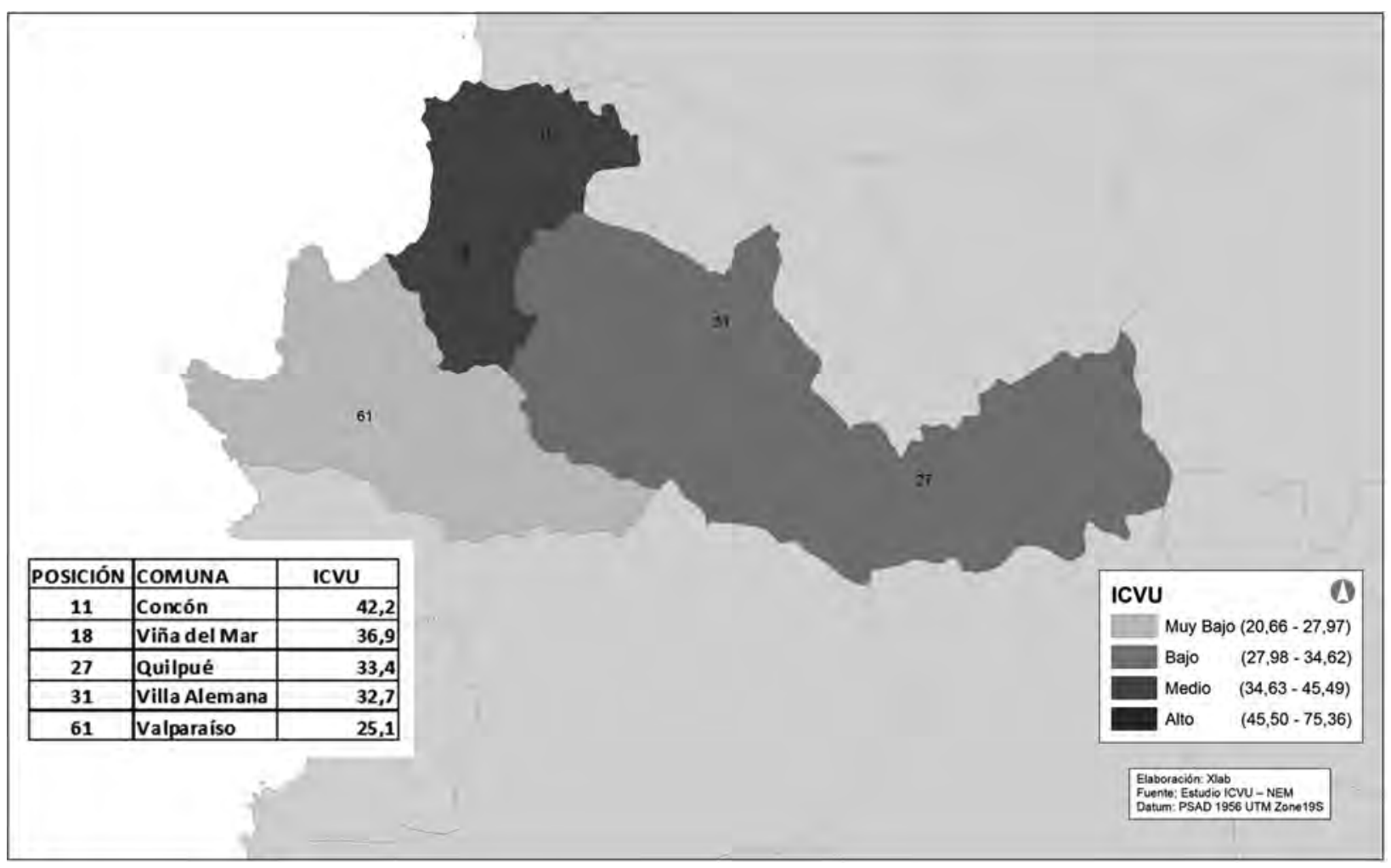

Fuente: elaboración propia, 2012.

Source: prepared by authors, 2012 
FIGURA 10: INDICADOR DE CALIDAD DE VIDA URBANA (ICVU). GRAN VALPARAÍSO, RESULTADOS 2012 GRAPHIC 10: 2012 RESULTS OF URBAN QUALITY OF LIFE INDEX (UQLI) FOR GREATER VALPARAÍSO

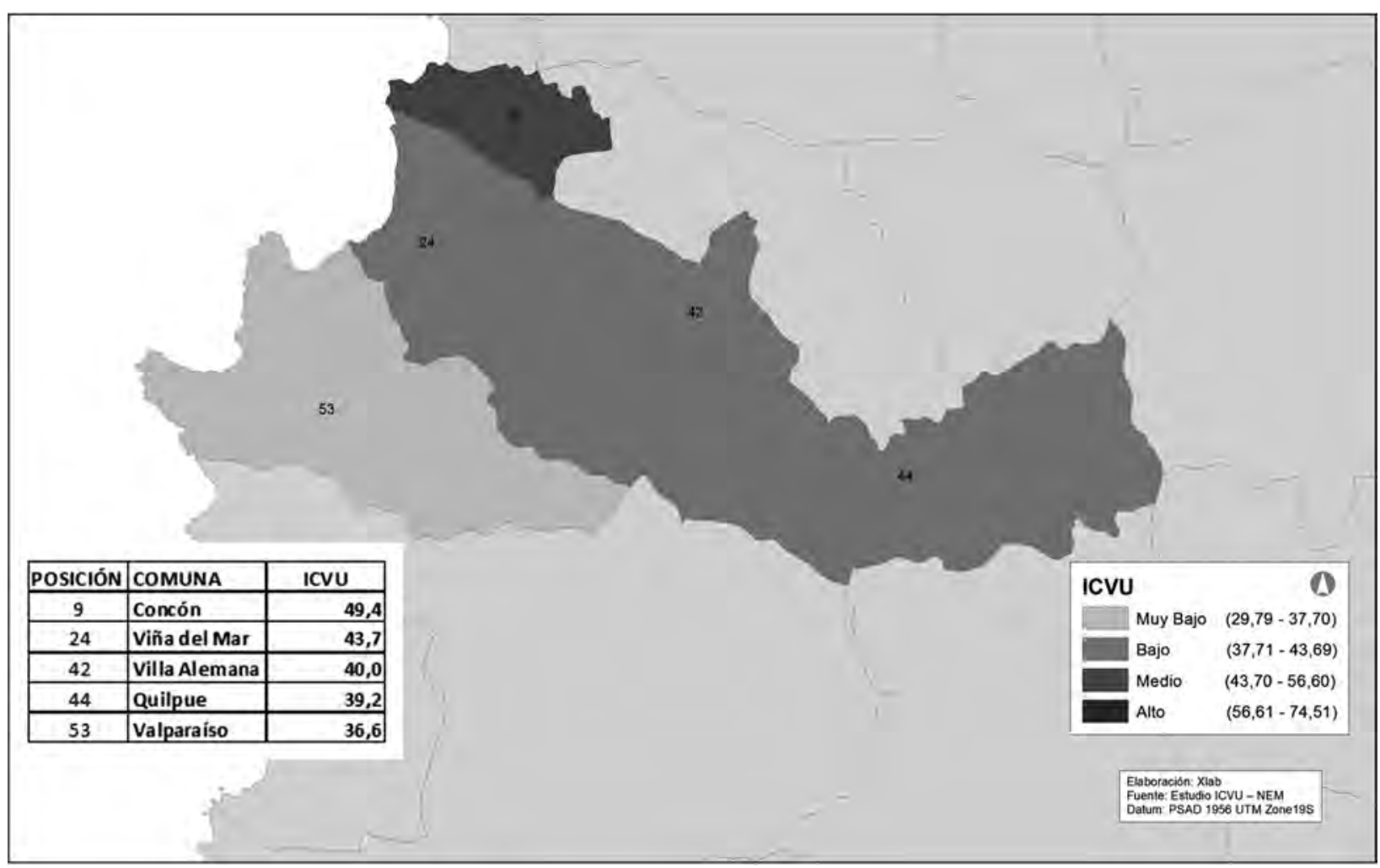

Fuente: elaboración propia, 2012.

Source: prepared by authors, 2012 
FIGURA 11: INDICADOR DE CALIDAD DE VIDA URBANA (ICVU). GRAN CONCEPCIÓN, RESULTADOS 2002 GRAPHIC 11: 2002 RESULTS OF URBAN QUALITY OF LIFE INDEX (UOLI) FOR GREATER CONCEPCIÓN

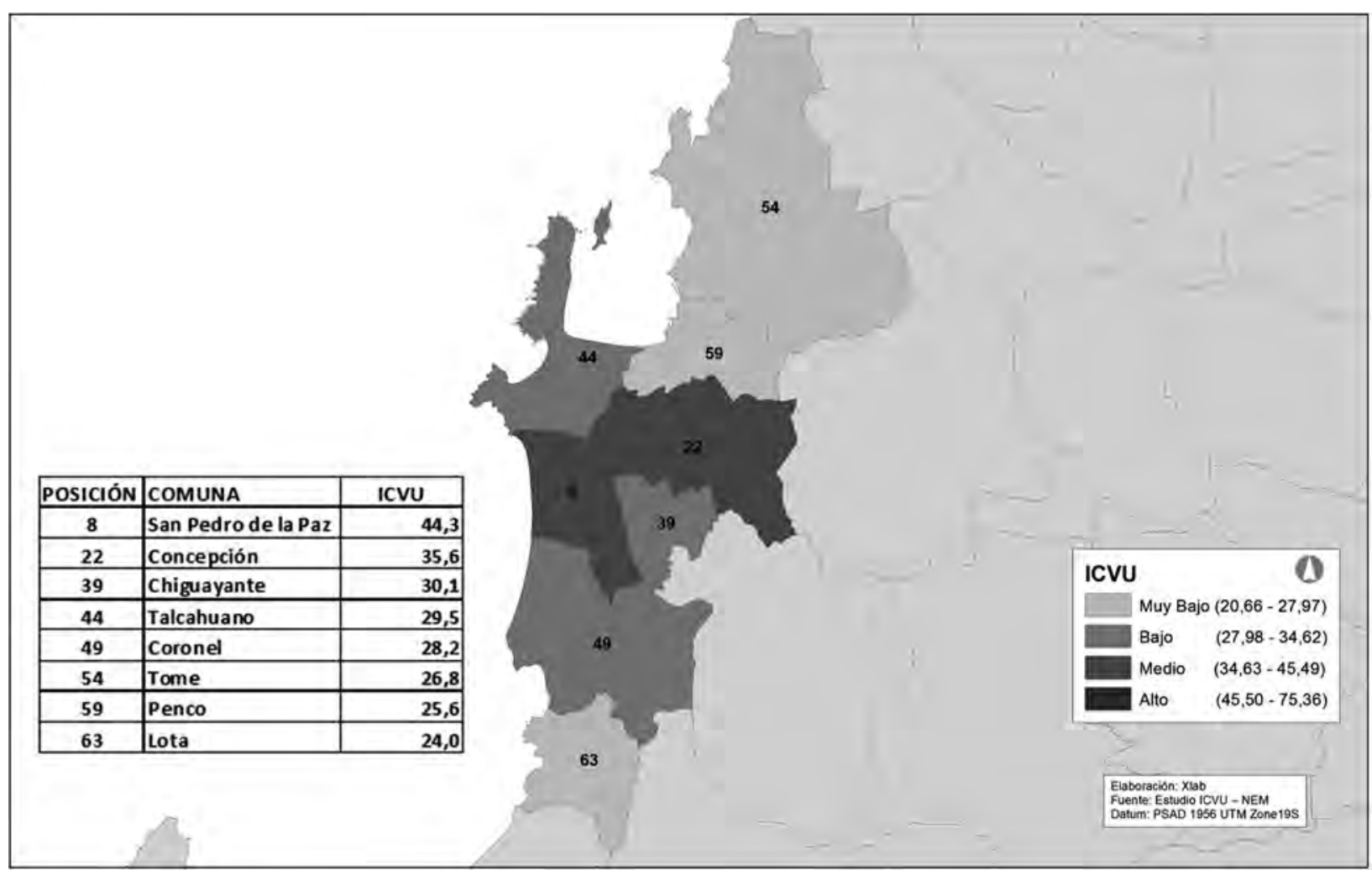

Fuente: elaboración propia, 2012.

Source: prepared by authors, 2012 
FIGURA 12: INDICADOR DE CALIDAD DE VIDA URBANA (ICVU). GRAN CONCEPCIÓN, RESULTADOS 2012 GRAPHIC 12: 2012 RESULTS OF URBAN QUALITY OF LIFE INDEX (UQLI) FOR GREATER CONCEPCIÓN

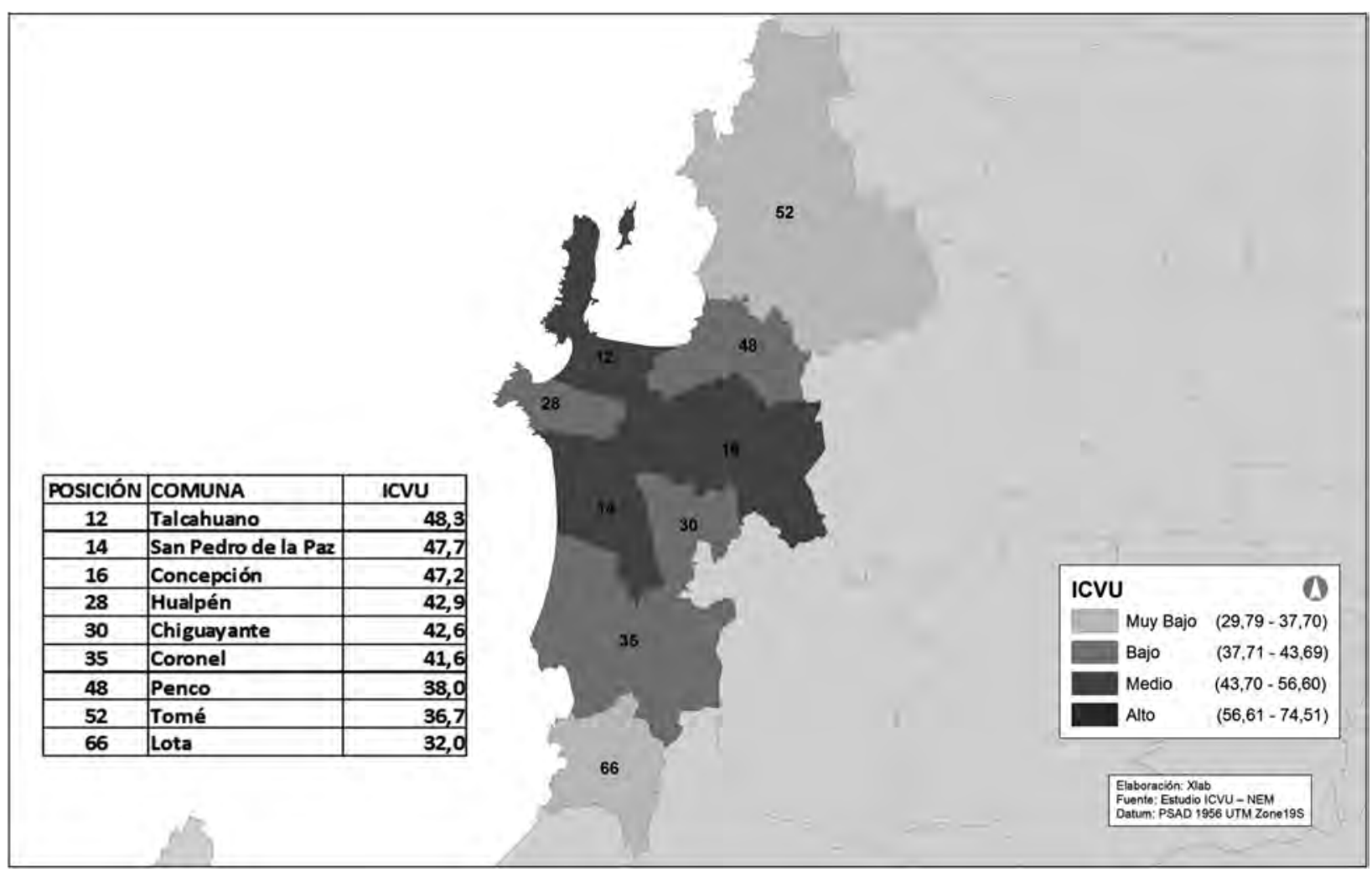

Fuente: elaboración propia, 2012.

Source: prepared by authors, 2012 
En el caso del Gran Valparaíso, si se compara la figura 9 y la figura 10 podemos advertir que en términos de evolución del ICVU, hay una situación de deterioro que también se ve reflejado en el ranking comunal, ya que mientras en el año 2002 de las cinco comunas dos estaban entre las 20 mejor posicionadas, solo Concón se mantiene en una buena posición en el ranking del año 2012 (lugar 9). Al mismo tiempo, el resto cae en el ranking o, como Valparaíso, se mantiene en los valores menores del ranking.

Respecto a la situación del Gran Concepción, la comparación de las figuras 11 y 12 da cuenta de los cambios en la calidad de vida urbana ocurridos en las nueve comunas que conforman esta área metropolitana. Así entonces, los resultados muestran una tendencia de mayor homogeneización entre comunas, para lo cual basta observar que entre la comuna mejor y peor ranqueada del año 2002 había poco más de 20 puntos, mientras que en 2012 esta brecha se reduce a poco más de 16 puntos.

Frente a las interrogantes respecto de los factores que pueden explicar los cambios producidos en la calidad de vida urbana experimentada por las comunas que son parte de este estudio, vale la pena detenerse a analizar las variables que participan en el cálculo del ICVU y que se expresan en las comunas en cada ámbito. En los gráficos que se muestran a continuación, la "variabilidad"
As for Greater Valparaíso, the comparison of graphic 9 and graphic 10 shows that, in terms of the evolution of UQLI scores, there is a deteriorating situation that is reflected in the ranked list of municipalities; in this sense, while two out of five municipalities were on the top twenty list back in 2002, Concon (ranked 9th) is the only municipality holding a favorable place in the 2012 list. The rest of the municipalities either experienced declines in their rankings or remained at the bottom of the list, as in the case of Valparaíso.

As for the situation of Greater Concepcion, the comparison of graphic 11 and graphic 12 shows the changes in the urban quality of life within the nine municipalities that compose this metropolitan area. Thus, the results suggest a greater homogenization trend among municipalities; in this regard, higher and lower ranked municipalities were separated by about 20 points in 2002, such a gap narrowed to approximately 16 points in 2012.

Regarding the questions about the factors that explain the changes in the urban quality of life within the analyzed municipalities, it is worth studying the variability of the indicators included in the estimation of the UQLI, which are expressed in each of the spheres of these municipalities. 
FIGURA 13: COMPARACIÓN DE LA VARIABILIDAD POR ÁMBITOS DEL ICVU 2002 V/S ICVU 2012 (\%). GRAPHIC 13: COMPARISON OF THE VARIABILITY PER SPHERES BETWEEN THE 2002 UQLI AND THE 2012 UQLI (\%)

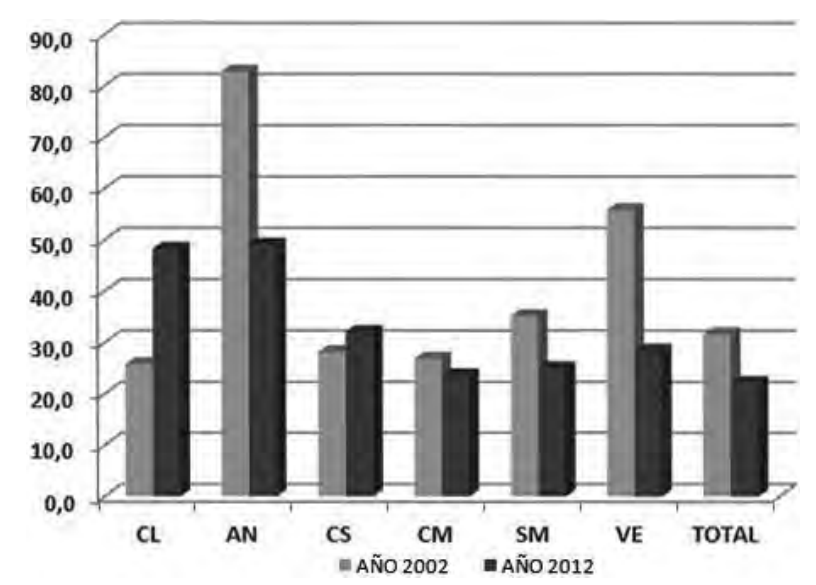

Fuente: elaboración propia, 2012. Source: prepared by authors, 2012

está representada por el coeficiente de variación $(\mathrm{CV}[\mathrm{x}])^{25}$ de los rankings en cada ámbito. La figura 13 muestra la variabilidad por ámbito para las comunas que son parte de este estudio, este gráfico permite observar la variabilidad dentro de cada ámbito en una escala corregida por el nivel medio

$25 \mathrm{CV}(\mathrm{x}]=100 *(\mathrm{~s}(\mathrm{x}) / \mathrm{x}(\mathrm{p}))$, donde $\mathrm{s}(\mathrm{x})=$ desviación estándar de la variable $\mathrm{x}, \mathrm{y} \mathrm{x}(\mathrm{p})$ es el promedio aritmético de la variable $\mathrm{x}$.

58 revista invi № 77 / Mayo 2013 / Volumen N² 28: 17-66

\section{FIGURA 14: COMPARACIÓN EN LA VARIABILIDAD POR ÁMBITOS ENTRE ICVU 2002 E ICVU $2012(\%)$. GRAPHIC 14: COMPARISON OF THE VARIABILITY PER SPHERES BETWEEN THE 2002 UQLI AND THE 2012 UOLI (\%)}

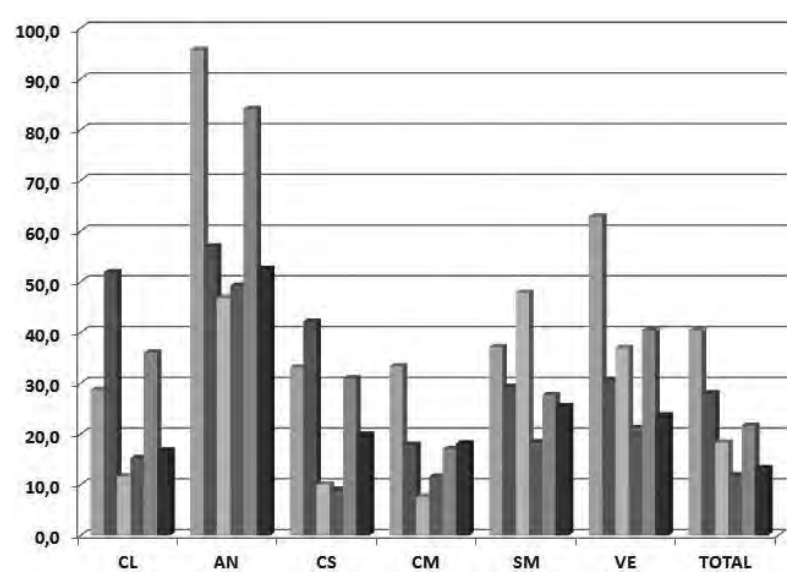

Fuente: elaboración propia, 2012

Source: prepared by authors, 2012.

The graphics below show that the "variability" is represented by the coefficient of variation $(C V[x])^{25}$ of ranked lists according to each sphere. Graphic 13 shows the variability per sphere in each of the analyzed municipalities, this graphic illustrates the variability of each sphere expressed

$25 \mathrm{CV}(\mathrm{x}]=100 *(\mathrm{~s}(\mathrm{x}) / \mathrm{x}(\mathrm{p}))$, where $\mathrm{s}(\mathrm{x})=$ standard deviation of the $\mathrm{x}$ variable; $x(p)$ represents the arithmetic average of the $x$ variable.

ARTICLE: Traces of the metropolization process in Chile / Arturo Maximiliano Orellana Ossandón, Pedro BannenLanata, Luis Alejandro Fuentes Arce, Horacio Gilabert Peralta, Karen Pape Casale 
o ranking medio. Esta variabilidad puede ser entendida como un indicador de la desigualdad que existe al interior de cada uno de los ámbitos.

Si se considera que un coeficiente de variación superior al 40\% constituye evidencia manifiesta de que la brecha entre comunas es significativa, entonces se puede afirmar que aquellos ámbitos que muestran alta variabilidad son aquellos que explican en mayor medida la brecha entre las comunas del estudio, más aún si su ponderación es mayor que el resto de los ámbitos. Bajo este criterio se constata que en el año 2002 las variabilidades en el ámbito Ambiente de Negocios $(82,9 \%)$ y en Vivienda y Entorno $(55,9 \%)$ eran muy significativas, mientras que en los otros cuatro ámbitos, la variabilidad era comparativamente más baja, la mayoría menor al 30\%, a excepción de Salud y Medio Ambiente (35,2\%). Estos resultados son significativos porque los dos ámbitos de alta variabilidad son los que explican el valor del ICVU en casi un $46 \%$ de acuerdo a las ponderaciones asignadas mediante la encuesta aplicada a expertos.

En una década, se puede evidenciar también en la figura 7 que la brecha de calidad de vida urbana disminuyó de manera importante, ya que la variabilidad pasa de $31,6 \%$ a $22,1 \%$. En cuatro de los seis ámbitos que constituyen el ICVU 2012 las variabilidades disminuyen. Las únicas excepciones son los ámbitos de Condiciones Laborales y Condiciones Socioculturales, que entre los años in a scale corrected by average level or average ranking. This variability can be understood as an inequity indicator of each sphere.

Bearing in mind that a coefficient of variation higher than $40 \%$ demonstrates a considerable gap among municipalities, it can be said, then, that those spheres showing high rates of variability explain the differences among the analyzed municipalities, especially if their weighted value is higher than the value of the rest of the spheres. Based on this criteria, while there was a considerable variability within the Business Environment and Housing and Living Environment spheres (82.9\% and 55.9\%, respectively) in 2002, the other four areas showed lower rates of variability, most of them below 30\% with the exception of Health and Environment (35.2\%.) These findings are important because the two spheres with higher rates of variability account for the $46 \%$ of the UQLI score according to the weighting factors applied after conducting the survey of experts.

Over a decade the urban quality of life gap has narrowed considerably, as variability indicators declined from $31.6 \%$ to $22.1 \%$ as observed in graphic 13. Four out of the six spheres that compose the 2012 UQLI saw their variability indicators reduced. The only exceptions are the spheres related to Work Status and Sociocultural 
2002 y 2012 aumentan su variabilidad del 25,8\% a $48,3 \%$ y de $28,1 \%$ a $32,1 \%$ respectivamente. Particularmente resulta notable el caso del ámbito de Condiciones Laborales, ya que una variabilidad cercana al 50\% entre comunas es síntoma de una manifiesta inequidad en este aspecto de la calidad de vida, aunque este pondere en el ICVU un poco menos del 10\%.

Por otro lado, resulta de gran importancia constatar que los ámbitos que marcaban el mayor diferencial entre comunas en el ICVU 2002, Ambiente de Negocio y Vivienda y Entorno, son aquellos donde se producen las mayores reducciones en la brecha de calidad de vida urbana en las comunas actualmente. Es así como al comparar los resultados del ICVU 2002 con los del 2012, se constata que en el caso de Ambiente de Negocios se pasa de un porcentaje de variabilidad de $82,9 \%$ a $49,1 \%$, mientras en el caso de Vivienda y Entorno se pasa de $55,9 \%$ a $28,1 \%$.

Ahora, si consideramos la variabilidad en cada ámbito entre las tres áreas metropolitanas principales de nuestro país, Gran Santiago, Gran Valparaíso y Gran Concepción, se obtienen los resultados que pueden observarse en la figura 14. Las barras grises representan los cambios en el Gran Santiago (las primeras), las barras verdes a Gran Valparaíso (las segundas) y las barras azules a Gran Concepción (las terceras), siendo las tonalidades más claras el reflejo del año 2002 y las más oscuras del 2012.
Conditions, which increased their variability from $25.8 \%$ to $48.3 \%$ and from $28.1 \%$ to $32.1 \%$, respectively, over the 2002-2012 period. Despite accounting for $10 \%$ of the UQLI, it is worth mentioning the case of the Work Status sphere, since a variability of 50\% among municipalities is a clear testimony of inequity in this quality of life aspect.

Likewise, it is important to note that the Business Environment and Housing and Living Environment spheres, which showed the largest differences among municipalities in the 2002 UQLI, present the greatest narrowing in the urban quality of life gap among municipalities today. By making a comparison between the 2002 UQLI and the 2012 UQLI, the variability average of the Business Environment and Housing and Living Environment areas dropped from $82.9 \%$ to $49.1 \%$ and from $55.9 \%$ to $28.1 \%$, respectively.

Graphic 14 shows the variability of each sphere among the main Chilean metropolitan areas: Greater Santiago, Greater Valparaiso and Greater Concepcion. Grey bars represent the changes in Greater Santiago (the first ones), green bars represent the changes in Greater Valparaiso (the second ones) and blue bars represent the changes in Greater Concepcion (the third ones); pale and dark tones show the indicators for the years 2002 and 2012, respectively. 
Al analizar los cambios globales del ICVU, se observa que para las tres áreas metropolitanas hay evidencia de que la brecha entre comunas disminuyó, incluso para el Gran Valparaíso (verde) y Gran Concepción (azul) a un porcentaje de variabilidad menor al 15\%, bajando en casi 7 puntos porcentuales en una década. En el caso del Gran Santiago (gris), la variabilidad según el cálculo del ICVU 2012 está en el 28\% por sobre el 22,1\% que se constata para las 67 comunas del estudio comparables.

Realizando un análisis comparado más fino, se pueden advertir matices en torno a los ámbitos que contribuyeron a disminuir la brecha entre comunas al interior de las áreas metropolitanas, así como aquellos ámbitos que contribuyeron a ampliar la brecha, siendo en términos de resultado final más significativo el efecto de los primeros que de los segundos para cada uno de estos conglomerados urbanos.

Si se procede a revisar por ámbitos, se advierte en una primera aproximación que Ambiente de $\mathrm{Ne}$ gocios constituye el ámbito donde se expresa la mayor variabilidad y a la vez la mayor disminución de la brecha entre comunas de las áreas metropolitanas para el caso del Gran Santiago y Gran Concepción, ambos disminuyen casi 30 puntos porcentuales, pero no así para el Gran Valparaíso, donde se aprecia un alza de poco más de dos puntos porcentuales. Luego, resulta significativo que
The analysis of the global changes of the UQLI suggests a narrowing in the gap among the municipalities belonging to the three metropolitan areas, even in Greater Valparaiso (green) and Greater Concepción (blue), whose variability averages fell below 15\%, dropping by 7 percentage points over a decade. According to the 2012 UQLI, the variability average of Greater Santiago is $28 \%$, which is above the $22.1 \%$ estimated for the 67 municipalities included in this research.

By means of a more detailed comparative analysis, it can be observed that there are different nuances emerging around the spheres that contributed to either narrowing or increasing the gap among municipalities within metropolitan areas; in terms of final results, the effect of the former on each of these urban conglomerates is more important than that of the latter.

At a first approximation, the analysis per sphere shows that the Business Environment area presents the higher variability and the greatest narrowing in the gap among the municipalities belonging to the metropolitan areas of Greater Santiago and Greater Concepción, where such a difference drops by 30 percentage points; this is not the case of Greater Valparaiso, which experienced an increase of about two percentage points. Likewise, there is a reduction in the gap 
en Vivienda y Entorno en todas las áreas metropolitanas hay una reducción en la brecha, lo que es muy importante ya que la ponderación de este ámbito en el valor del ICVU es cercana al 30\%. Por su parte, en el ámbito de Salud y Medio Ambiente también hay un efecto de disminución en la brecha de calidad de vida, particularmente para el Gran Valparaíso, donde la brecha disminuye en casi 30 puntos porcentuales. Para este ámbito, cuya ponderación es del 18,8\% ocupando el segundo lugar en incidencia después de Vivienda y Entorno, la variabilidad en todas las áreas metropolitanas es menor al 30\% de acuerdo al ICVU 2012.

En los otros ámbitos el comportamiento resulta dispar entre las tres áreas metropolitanas, ya que en el caso de Condiciones Laborales existe un alza significativa para el Gran Santiago, pasando de $28,6 \%$ a $51,9 \%$, cifra que evidencia un significativo aumento de la brecha en este ámbito en términos de calidad de vida urbana. Si bien el Gran Valparaíso también presenta un alza, resulta que al mismo tiempo su variabilidad es muy baja pues apenas supera el 15\% en el cálculo del ICVU 2012. Por el contrario, en el caso del Gran Concepción la disminución en la brecha es significativa, ya que se pasa de $36,0 \%$ a $16,7 \%$, es decir, casi 20 puntos porcentuales.

En el caso de Condiciones Socioculturales, el aumento de la variabilidad en el Gran Santiago es relevante, ya que aumenta de $33,1 \%$ a $42,1 \%$, lo related to Housing and Living Environment in all metropolitan areas; this is an important event since the weighted value of this sphere within the UQLI is about 30\%. In addition, the Health and Environment sphere shows a decline in the urban quality of life gap, especially in the case of Greater Valparaíso, where such a distance is reduced by 30 percentage points. According to the 2012 UQLI, this sphere, whose weighted value is 18.8\% -the second incidence area behind Housing and Living Environment-, shows variability below $30 \%$ in metropolitan areas.

Regarding the rest of the spheres, there are different behaviors among the three metropolitan areas; in this sense, the average of the Work Status sphere rises from $28,6 \%$ to $51.9 \%$ in the case of Greater Santiago, such a figure shows an important increase in this gap as far as quality of life is concerned. As for Greater Valparaiso, despite experiencing an average increase as well, its variability is very low as it barely rises above 15\% according to the 2012 UQLI. In contrast, Greater Concepción shows a considerable decline as its gap narrowed from $36.0 \%$ to $16.7 \%$, almost 20 percentage points.

In relation to Sociocultural Conditions, there is an important increase in variability experienced by Greater Santiago, as it rises from 33.1\% to 
que evidencia un aumento en la desigualdad en este ámbito, mientras que para el Gran Valparaíso y Gran Concepción hay una disminución en la brecha y además una baja incidencia en la variabilidad, con menos del 20\%. Este ámbito pesa un $17,2 \%$ en la ponderación, siendo el tercer ámbito en incidencia en el valor del ICVU.

Por último, en Conectividad y Movilidad, los resultados de la figura 13 muestran una disminución en la brecha, pasando de $33,3 \%$ a $17,9 \%$. Por otra parte, para ambas áreas metropolitanas la situación es lo contrario, es decir, la brecha aumentó aunque no muy significativamente, siendo para ambos casos aún la variabilidad menor al 20\%.

\section{Conclusiones}

Al comparar los resultados obtenidos entre el ICVU 2000 y el ICVU 2012, estos entregan evidencia inequívoca de que la calidad de vida entre comunas urbanas en Chile ha disminuido en la última década. Sin embargo, persiste un diferencial importante que se manifiesta en las grandes áreas metropolitanas, especialmente en el caso del Gran Santiago, donde además se sitúan las dos realidades extremas del país, que se ven reflejadas en el ranking del ICVU. Los ámbitos de Ambiente de Negocios y Vivienda y Entorno, que en conjunto inciden en casi un $46 \%$ en la ponderación del ICVU, resultan ser los que experimentaron en este
$42.1 \%$, thus revealing a growth in inequity within this sphere; conversely, Greater Valparaíso and Greater Concepción, apart from narrowing their gaps, present low incidence rates of less than $20 \%$. Such a sphere accounts for $17.2 \%$ of the weighted total, becoming the third area of incidence within the UQLI.

Lastly, Graphic 13 shows the decrease in the Connectivity and Mobility gap, which drops from $33.3 \%$ to $17.9 \%$. In contrast, both cases show a slight increase in this gap, with a variability below $20 \%$.

\section{Conclusions}

The comparison of the results obtained from the 2002 UQLI and the 2012 UQLI provides strong evidence that there has been a decrease in the quality of life among Chilean urban municipalities over the last decade. However, there is an important gap that still exists in large metropolitan areas, especially in the case of Greater Santiago, which involves the two opposing realities of the country; such a scenario is reflected in the UQLI ranked list. The Business Environment and Housing and Living Environment spheres, which account for nearly $46 \%$ of the UQLI weighted total, have considerably reduced their gaps; this is an 
período una significativa disminución en la brecha, hecho de gran importancia ya que mostraban también una variabilidad alta.

La aplicación del ICVU tiene el mérito que permite establecer una relación más directa entre las causales que explican la menor o mayor calidad de vida que ofrece una comuna, en relación al conjunto de iniciativas de carácter económico, social y ambiental que desarrollan el sector público, el sector privado y la propia sociedad civil. Desde este punto de vista, contar con un instrumento de monitoreo y seguimiento validado que permita comparar y evaluar la evolución de la calidad de vida urbana en Chile, no solo constituye un instrumento de gran utilidad para tomadores de decisiones en el afán de priorizar, focalizar y evaluar el impacto de sus actuaciones en el espacio urbano, sino que posibilita descifrar algunas incógnitas importantes sobre el por qué existen marcadas diferencias en la calidad de vida entre comunas al interior de las áreas metropolitanas.

La tesis planteada por Veltz $z^{26}$, en relación que las áreas metropolitanas a escala global tienden a parecerse y en su interior a diferenciarse, parece cumplirse a cabalidad para el caso chileno. Esta ciudad que lidera o se ubica casi sin excepción entre las ciudades latinoamericanas mejor posicionadas en todos los rankings internacionales (MERCER,

26 Veltz, 1999.

64 revista invi № 77 / Mayo 2013 / Volumen N² 28: 17-66 important event, as they showed high levels of variability.

The application of the UQLI has the advantage of establishing a direct relationship between the factors that prompt the lower or higher quality of life offered by a municipality in relation to the set of economic, social and environmental initiatives developed by the public and private sector and the civil society itself. From this perspective, having a validated monitoring and follow-up system aimed at comparing and evaluating the evolution of quality of life in Chile is not only a useful instrument for policy makers in their task of prioritizing, focusing and assessing the impact of their actions on the urban space, but also allows to decipher important questions regarding as to why there are strong quality of life differences among municipalities within metropolitan areas.

Velt $z^{26}$ proposes that metropolitan areas tend to be alike at a global scale and differ at an internal scale and this thesis seems to be fully completed in the case of Greater Santiago. This city, which is at the top or among the top Latin American cities in all international lists (MERCER, MasterCard, The Economist, IABD, among others), hides the two faces of urban development in Chile; such

26 Veltz, 1999 
MasterCard, The Economist, BID, entre otros), esconde en su interior las dos caras del desarrollo urbano en Chile, reflejado en comunas que alcanzan estándares de calidad de vida comparables a ciudades del primer mundo y otras comunas que concentran una gran cantidad de problemáticas asociadas al proceso de configuración socio-territorial de su área metropolitana.

Los patrones que se deducen de los análisis que arroja este estudio, muestran que las áreas metropolitanas constituyen un ámbito del desarrollo urbano de primera prioridad respecto a la urgencia para la política pública. Los resultados muestran desequilibrios manifiestos entre comunas, particularmente para el caso del Gran Santiago, Gran Concepción y Gran Valparaíso. La ausencia de un modelo institucional para estas áreas metropolitanas bajo un gobierno único, una planificación integral y una gestión intersectorial coordinada, probablemente incida en que en un futuro próximo tampoco se tengan respuestas adecuadas en materia de políticas públicas para otras realidades metropolitanas en ciernes (La Serena-Coquimbo, RancaguaMachalí, Temuco-Padre Las Casas, Puerto MonttPuerto Varas, entre otras). En definitiva, dónde y en qué medida se focalice la inversión pública y privada, así como las formas como se configura el territorio metropolitano, no resulta ser un asunto menor en términos de calidad de vida urbana. a fact is reflected in municipalities with quality of life standards equal to those of cities from developed countries and municipalities that concentrate large amount of problems related to the socio-territorial configuration process of their metropolitan area.

Patterns derived from the analysis provided by this research show that metropolitan areas are a high priority aspect of urban development in terms of urgency for public policy. However, the results show clear imbalances among municipalities, particularly for the cases of Greater Santiago, Greater Concepción and Greater Valparaíso. The lack of an institutional model for these metropolitan areas which are under a single administration, an integral planning and a coordinated crosssectored management will probably have an impact on other emerging metropolitan areas, where probably in the near future there will not be adequate answers on public policies issues either (La Serena-Coquimbo, Rancagua-Machali, Temuco-Padre las Casas, Puerto Montt-Puerto Varas, among other). Summarising, where and to what extent public and private investment is focused, as well as the different ways of how the metropolitan territory is configured, are not a minor issue in terms of urban quality of life. 
Finalmente, la complejidad y dinamismo que impone el desarrollo urbano actual, exige más que nunca reconocer la huella de la metropolización en nuestro país, descifrar las razones que marcan las diferencias y explicar por qué ciertas comunas de nuestras áreas metropolitanas concentran los mayores atributos en materia de calidad de vida y otras comunas son un depositario de un sinnúmero de externalidades no deseadas, las cuales además afectan severamente la condición de calidad de vida de quienes las habitan. Este estudio considera que hace un aporte importante en ese propósito.

\section{Bibliografía}

BID. Calidad de vida: más allá de los hechos. [En línea]. Banco Interamericano de Desarrollo. 2008. ISBN: 978-1-59782-083-7. Serie Desarrollo en las Américas. Disponible en: http://www.iadb. org/es/investigacion-y-datos/detalles-de-publicacion,3169.html?pub_id=b-632

FADDA, Giulietta y JIRÓN, Paola. Calidad de vida: una metodología para la investigación urbana. Revista de la Escuela de Economía y Negocios UNSAM. (1): 175-187, marzo 1999.

MATTOS, Carlos de. Globalización y metamorfosis metropolitana en América Latina. De la ciudad a lo urbano generalizado. [En línea]. Revista de Geografía Norte Grande. (47): 81-104. 2002. ISSN
Finally, the complexity and dynamism imposed by the current urban development demand the acknowledgment of the traces of the metropolization process in Chile and deciphering the reasons that determine the differences among municipalities and explain why some of them concentrate the greatest attributes in terms of quality of life and others act as the repository of undesired externalities, which severely affect the quality of life of those who inhabit these places. In this sense, this research is an important contribution to this end.

0718-3402. Disponible en: http://dx.doi.org/ 10.4067/S0718-34022010000300005

UNESCO. Final report expert meeting on indicators of environmental quality and the quality of life. [En línea]. En: Indicators of environmental quaility and quality of life. Paris, France, UNESCO. 1978. p. 89-96. Reports and papers in the social sciences, $N^{\circ} 38$. ISBN 92-3-1 01 539-7. Disponible en: http://unesdoc.unesco.org/ images/0003/000367/036722eo.pdf

VELTZ, Pierre. Mundialización, ciudades y territorios: La economía del archipiélago. Barcelona, Ariel. 1999. 